\title{
The precursor tRNA 3'-CCA interaction with Escherichia coli RNase P RNA is essential for catalysis by RNase $P$ in vivo
}

\author{
BARBARA WEGSCHEID and ROLAND K. HARTMANN \\ Institut für Pharmazeutische Chemie, Philipps-Universität Marburg, D-35037 Marburg, Germany
}

\begin{abstract}
The L15 region of Escherichia coli RNase P RNA forms two Watson-Crick base pairs with precursor tRNA $3^{\prime}$-CCA termini (G292-C $C_{75}$ and G293-C $C_{74}$ ). Here, we analyzed the phenotypes associated with disruption of the G292-C 75 or G293-C $_{74}$ pair in vivo. Mutant RNase P RNA alleles ( $r n p B C 292$ and $r n p B C 293$ ) caused severe growth defects in the $E$. coli rnpB mutant strain DW2 and abolished growth in the newly constructed mutant strain BW, in which chromosomal rnpB expression strictly

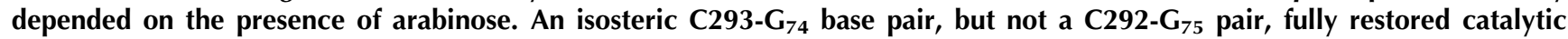
performance in vivo, as shown for processing of precursor 4.5S RNA. This demonstrates that the base identity of G292, but not G293, contributes to the catalytic process in vivo. Activity assays with mutant RNase $P$ holoenzymes assembled in vivo or in vitro revealed that the $\mathrm{C292/293}$ mutations cause a severe functional defect at low $\mathrm{Mg}^{2+}$ concentrations (2 $\left.\mathrm{mM}\right)$, which we infer to be on the level of catalytically important $\mathrm{Mg}^{2+}$ recruitment. At $4.5 \mathrm{mM} \mathrm{Mg}{ }^{2+}$, activity of mutant relative to the wild-type holoenzyme, was decreased only about twofold, but 13 - to 24 -fold at $2 \mathrm{mM} \mathrm{Mg}^{2+}$. Moreover, our findings make it unlikely that the C292/293 phenotypes include significant contributions from defects in protein binding, substrate affinity, or RNA degradation. However, native PAGE experiments revealed nonidentical RNA folding equilibria for the wild-type versus mutant RNase P RNAs, in a buffer- and preincubation-dependent manner. Thus, we cannot exclude that altered folding of the mutant RNAs may have also contributed to their in vivo defect.
\end{abstract}

Keywords: E. coli ribonuclease P; CCA-RNase P RNA interaction; in vivo complementation studies; point mutations

\section{INTRODUCTION}

Ribonuclease $\mathrm{P}$ (RNase $\mathrm{P}$ ) is an essential ribonucleoprotein enzyme responsible for the $5^{\prime}$-end maturation of tRNAs (Altman and Kirsebom 1999; Schön 1999; Hartmann and Hartmann 2003; Evans et al. 2006). The bacterial RNase P holoenzyme consists of an RNA subunit of $\sim 380$ nucleotides ( $\mathrm{nt})$ and a small basic protein $(\sim 13 \mathrm{kDa})$, and in vitro, RNA subunits of bacterial RNase $\mathrm{P}$ enzymes are catalytically active in the absence of the protein subunit (Guerrier-Takada et al. 1983). Bacterial RNase P enzymes recognize the stacked acceptor stem-T arm module of

Reprint requests to: Roland K. Hartmann, Institut für Pharmazeutische Chemie, Philipps-Universität Marburg, Marbacher Weg 6, D-35037 Marburg, Germany; e-mail: roland.hartmann@staff.uni-marburg.de; fax: 6421-2825854.

Article published online ahead of print. Article and publication date are at http://www.rnajournal.org/cgi/doi/10.1261/rna.188306. precursor tRNA (ptRNA) substrates, including specific elements at the cleavage site, such as the residue at nucleotide -1 and the $3^{\prime}{ }_{-73} \mathrm{NCCA}_{76}$ end (Harris and Christian 2003). The two cytosines of tRNA $3^{\prime}$-CCA $\left(C_{74}\right.$ and $\left.C_{75}\right)$ termini were shown to form Watson-Crick (WC) base pairs with two conserved G residues (G292 and G293) in the loop L15 of Escherichia coli RNase P RNA (Fig. 1; Kirsebom and Svärd 1994). This interaction provides a substantial contribution to the free energy of ptRNA binding in vitro (Hardt et al. 1995; Oh et al. 1998; Busch et al. 2000), supports selection of the correct cleavage site (Kirsebom and Svärd 1994), and was suggested to play a role in the binding of catalytic $\mathrm{Mg}^{2+}$ (Oh et al. 1998; Busch et al. 2000). Another in vitro study provided evidence that base-pairing with $3^{\prime}$-CCA is also relevant to cleavage site selection in the holoenzyme reaction (Svärd et al. 1996).

We previously reported a kinetic and thermodynamic in vitro analysis of the $\mathrm{G} 292-\mathrm{C}_{75}$ and $\mathrm{G} 293-\mathrm{C}_{74}$ base-pairing 


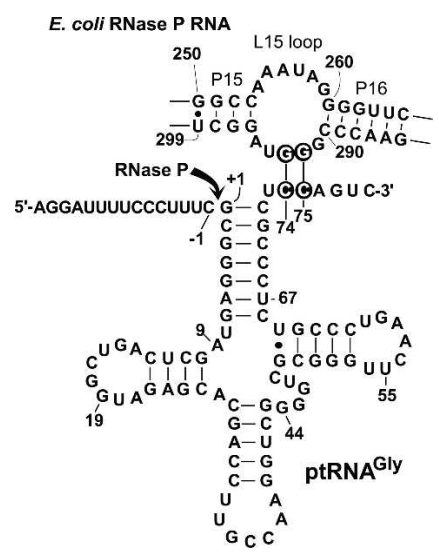

FIGURE 1. Interaction of Thermus thermophilus ptRNA ${ }^{\text {Gly }}$ with the L15 loop of E. coli RNase P RNA. Highlighted nucleotides mark the sites of mutation investigated in this study. The arrow indicates the canonical RNase $\mathrm{P}$ cleavage site (between nucleotides -1 and +1 ). Nucleotides 291-295 of E. coli RNase P RNA are also termed J16/15.

interaction in the reaction catalyzed by E. coli RNase $\mathrm{P}$ RNA (Busch et al. 2000). The results were based on the study of wild-type RNase P RNA along with two variants carrying a single G-to-C exchange (C292 or C293), either acting on wild-type ptRNA ${ }^{\text {Gly }}$ or derivatives with a compensatory mutation in the tRNA $3^{\prime}$-end $\left(3^{\prime}-\mathbf{G}_{74} \mathrm{CA}\right.$ or $3^{\prime}$ $\mathrm{CG}_{75} \mathrm{~A}$ ) (Fig. 1). Disruption of either of the two intermolecular base pairs largely reduced ground state binding to E. coli RNase P RNA. Disruption of the $\mathrm{G}_{2} 93-\mathrm{C}_{74}$ pair had a less detrimental effect on the single turnover kinetic parameters than did disruption of the $\mathrm{G}_{2} 92-\mathrm{C}_{75}$ pair (Busch et al. 2000). This was consistent with previous findings (Oh et al. 1998), suggesting that the reduction in the efficiency of cleavage of a mutant ptRNA-CU $\mathrm{U}_{75} \mathrm{~A}$ substrate resulted from impaired binding of $\mathrm{Mg}^{2+}$ important for catalysis. Restoration of base-pairing by compensatory base exchanges in the substrate $\left(\mathrm{C} 293-\mathrm{G}_{74}\right.$ and C292- $\mathrm{G}_{75}$ ) restored catalytic performance in vitro, almost fully for the C293- $G_{74}$, but clearly less for the $C 292-G_{75}$ combination (Busch et al. 2000).

Here, we investigated the role of the CCA interaction in vivo in E. coli to clarify how far previous in vitro findings, observed under unphysiologically high $\mathrm{Mg}^{2+}$ concentrations, are relevant to the cellular situation. This included the construction of a novel E. coli $\operatorname{rnp} B$ mutant strain (named BW), in which chromosomal $r p p B$ expression is efficiently knocked down when glucose is substituted for arabinose in growth media. We demonstrate that the $r n p B C 292$ and $r n p B C 293$ mutant alleles are lethal in strain BW. In the case of the C293, but not the C292 mutant, a compensatory mutation in the substrate $3^{\prime}$ end fully restored processing capacity in vivo and in vitro. Processing assays with partially purified and in vitro assembled holoenzymes further revealed that the defect of the C292/ 293 enzymes is most evident at free $\mathrm{Mg}^{2+}$ concentrations assumed to be close to those in vivo. Since our results indicate that the phenotypes of the C292 and C293 mutations do not include substantial contributions from defects in protein binding, substrate affinity, or RNA degradation, we propose that the defect is primarily on the level of recruitment of catalytically important $\mathrm{Mg}^{2+}$. Native PAGE experiments revealed nonidentical RNA folding equilibria for the wild-type versus mutant RNase P RNAs, in a buffer- and preincubation-dependent manner. Thus, a contribution from nonnative folding to the defect of the mutant RNAs in vivo cannot be ruled out at present.

\section{RESULTS}

\section{In vivo complementation in $E$. coli DW2}

To investigate the ptRNA 3'-CCA interaction with RNase P RNA under in vivo conditions, plasmids carrying the wildtype RNase P RNA gene ( $r n p B w t)$ or the C292 or C293 mutant alleles ( $r n p B C 292, r n p B C 293)$ were introduced into the temperature-sensitive E. coli RNase P mutant strain DW2/pDW160. In strain DW2/pDW160, the chromosomal gene encoding the RNase P RNA subunit $(r n p B)$ is replaced with a chloramphenicol resistance cassette and a complementing $\operatorname{rnp} B$ gene is provided on a plasmid (pDW160) temperature sensitive for replication (Waugh and Pace, 1990). Suppression of the conditionally lethal phenotype at $43^{\circ} \mathrm{C}$ is achieved by expression of functional RNase P RNA from a second compatible plasmid.

As expected, E. coli r $n p B$ wt provided on the multicopy plasmid pSP64 rescued growth of the mutant strain at the nonpermissive temperature of $43^{\circ} \mathrm{C}$ (Table 1). The rnpBC292 mutant allele caused only a partial rescue, and rnpBC293 showed very weak complementation. For bacteria transformed with $\operatorname{rnpBC} 292$ and $\operatorname{rnpBC} 293$ mutant alleles and grown at $43^{\circ} \mathrm{C}$, the corresponding mutant RNAs were verified to be the dominant RNase P RNA species in the cell by primer extension analyses (data not shown; see Materials and Methods). These control experiments excluded reversion of mutant alleles to the wild-type sequence.

\section{Construction of a novel $E$. coli rnpB knockdown strain}

The impaired phenotype of the $\operatorname{rnp} B \mathrm{C} 293$ allele relative to $r n p B C 292$ in E. coli DW2 cells (Table 1) was the reverse of what we had expected based on our previous in vitro results (Busch et al. 2000). Moreover, the DW2 strain has the drawback that complementation analyses are performed under stress conditions at $43^{\circ} \mathrm{C}$. The heat-shock response has a global effect on gene expression (Richmond et al. 1999; Li et al. 2003), and induced metabolic changes could alter the mutant phenotype. Also, even cells expressing the 
TABLE 1. Complementation analyses of $E$. coli RNase P mutant strain DW2 by rnpB alleles

\begin{tabular}{lll}
\hline & \multicolumn{2}{c}{ DW2/pDW160 } \\
\hline RNase P RNA variant & $30^{\circ} \mathrm{C}$ & $43^{\circ} \mathrm{C}$ \\
pSP64 E. coli rnpBwt & +++ & $+++^{\mathrm{a}}$ \\
pSP64 E. coli rnpBC292 & +++ & ++ \\
pSP64 E. coli rnpBC293 & +++ & $(+)$ \\
pSP64 & +++ & - \\
\hline
\end{tabular}

Growth of mutant strain DW2 transformed with different $r n p B$ alleles (E. coli rnpBwt, rnpBC292, and $r n p B C 293$ ) was analyzed on $\mathrm{LB}$ plates at the permissive $\left(30^{\circ} \mathrm{C}\right)$ and nonpermissive $\left(43^{\circ} \mathrm{C}\right)$ temperature. $+++>++>(+)>-$, decreasing order of complementation efficiency based on number and size of colonies.

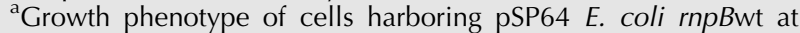
$43^{\circ} \mathrm{C}$ was set as standard, although colonies at $43^{\circ} \mathrm{C}$ were smaller than at $30^{\circ} \mathrm{C}$.

wild-type allele (pSP64 E. coli rnpBwt) (Table 1) grew slower at $43^{\circ} \mathrm{C}$ compared with $30^{\circ} \mathrm{C}$. We thus constructed a novel E. coli mutant strain in which the chromosomal $r n p B$ gene was put under control of the arabinose promoter and repressor system (Fig. 2A). In the absence of arabinose and presence of glucose, $r n p B$ expression is switched off, and cell survival depends on a second functional $r n p B$ gene provided on a plasmid. The E. coli mutant strain (termed BW) exactly displayed the anticipated phenotype (Fig. 2B). In the BW strain, only the $r n p B w t$ allele, but not $r n p B C 292$ and $r n p B C 293$, restored growth in the absence of arabinose (Fig. 2C; Table 2A).

\section{Defect in maturation exemplified for 4.5S RNA}

We then analyzed if the $\operatorname{rnpBC} 292$ and $r n p B C 293$ mutant alleles are associated with an RNase $\mathrm{P}$ processing defect in BW bacteria. For this purpose, BW cells expressing $r n p B w t$, rnpBC292, or rnpBC293 from plasmid pACYC177 were initially grown in medium containing arabinose, followed by transfer into medium without arabinose, further incubation for $3 \mathrm{~h}$ at $37^{\circ} \mathrm{C}$, and preparation of total cellular RNA. We then analyzed processing of $4.5 \mathrm{~S}$ RNA, a prominent non-tRNA substrate of $E$. coli RNase P (Bothwell et al. 1976; Peck-Miller and Altman 1991), by primer extension (Fig. 3). Exclusively mature 4.5S RNA was detected in RNA extracts from cells expressing plasmid-encoded rnpBwt (Fig. 3, lane 2), whereas cells harboring $r n p B C 292$ and rnpBC293 accumulated a 4.5S RNA precursor extended by $3 \mathrm{nt}$ at the $5^{\prime}$ end. Since the native $4.5 \mathrm{~S}$ RNA primary transcript carries a $5^{\prime}$ leader of 24 nt (see Fig. 4), nucleolytic activities other than RNase $\mathrm{P}$ apparently trimmed the leader to $3 \mathrm{nt}$. Likewise, accumulation of immature RNA with an extra 2-5 nt at the $5^{\prime}$ end were observed for the bacteriophage $\mathrm{P} 1 / \mathrm{P} 7$ regulatory $\mathrm{C} 4 \mathrm{RNA}$, another nontRNA substrate of E. coli RNase P, when processing by RNase $\mathrm{P}$ was defective (Hartmann et al. 1995). The ratio of
5 '-extended to mature 4.5S RNA was reproducibly higher in the $r m p B C 292$ than $r n p B C 293$ background (Fig. 3, lanes $3,4)$, providing evidence that the processing defect of the C292 mutant RNA is more severe than that of the C293 variant, in line with the kinetic in vitro data (Busch et al. 2000).

\section{A}
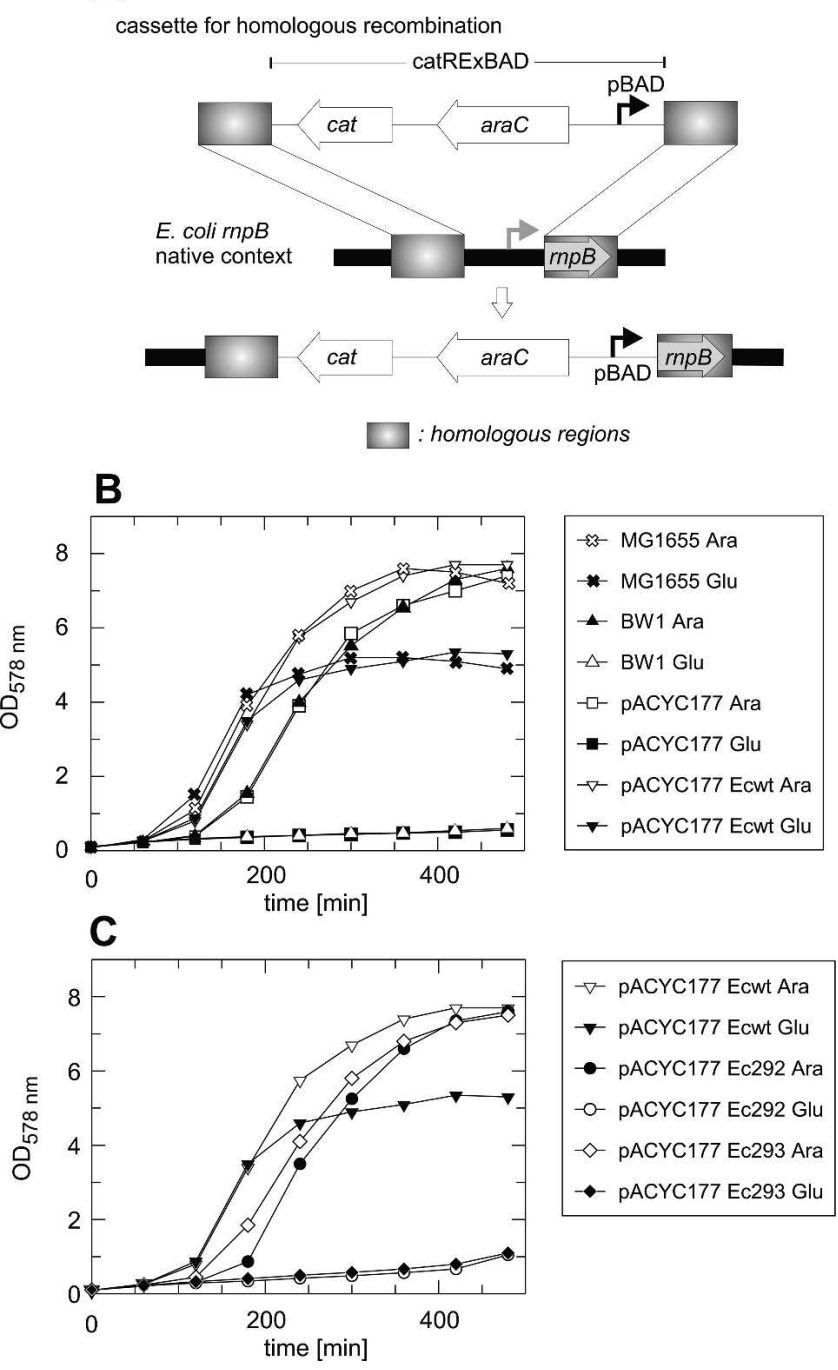

FIGURE 2. Construction and analysis of the E. coli rnpB mutant strain BW. (A) Schematic presentation of the strain construction strategy. The native $r n p B$ promoter region was replaced with a cassette (catRExBAD, $2136 \mathrm{bp}$ ) carrying the chloramphenicol resistance gene (cat), a gene coding for an arabinose operon regulatory protein $(\operatorname{araC})$, and the arabinose-inducible pBAD promoter. The cassette for homologous recombination (2669 bp) additionally contained flanking regions identical in sequence to $E$. coli $\operatorname{rnp} B$ and to a segment upstream of $r m p B$. (B) Cell growth rescue of strain BW in the presence of glucose (Glu) with a plasmid-encoded copy of E. coli $\operatorname{rnpB}$ (pACYC177 Ecwt). Note that growth curves in the presence of glucose versus arabinose differ in the same manner for strain BW and its progenitor MG1655. (C) Growth analyses of BW bacteria expressing plasmid-encoded rnpBwt, $r n p B C 292$, or $r n p B C 293$ alleles (pACYC177 Ecwt, Ec292, or Ec293) in the presence of arabinose (Ara) or glucose (Glu). 
TABLE 2. Complementation analyses in E. coli RNase P mutant strain BW

(A) Complementation of E. coli RNase P mutant strain BW by rnpB alleles

\begin{tabular}{lcc}
\hline RNase P RNA variant & $10 \mathrm{mM}$ arabinose & $0.5 \%$ glucose \\
\hline pACYC177 E. coli rnpBwt & + & + \\
pACYC177 E. coli rnpBC292 & + & - \\
pACYC177 E. coli rnpBC293 & + & - \\
pACYC177 & + & - \\
\hline
\end{tabular}

(B) Complementation of E. coli RNase P mutant strain BW by rnpB alleles and simultaneous overexpression of $E$. coli rnpA

\begin{tabular}{llcc}
\hline RNase P RNA variant & \multicolumn{1}{c}{$r n p A^{\text {a }}$} & $10 \mathrm{mM}$ arabinose, $1 \mathrm{mM}$ IPTG & $0.5 \%$ glucose, $1 \mathrm{mM}$ IPTG \\
\hline pACYC177 E. coli rnpBwt & + E. coli rnpA & + & + \\
pACYC177 E. coli rnpBC292 & + E. coli rnpA & + & $-{ }^{\mathrm{b}}$ \\
pACYC177 E. coli rnpBC293 & + E. coli rnpA & + & $+{ }^{\mathrm{c}}$ \\
pACYC177 & + E. coli rnpA & + & - \\
\hline
\end{tabular}

Growth of BW bacteria transformed with different $r n p B$ alleles (E. coli rnpBwt, rnpBC292 and rnpBC293, part $A$ ) and simultaneously overexpressing E. coli $\mathrm{rnpA}$ (part B); growth was analyzed on LB plates in the presence of $10 \mathrm{mM}$ arabinose or $0.5 \%$ (w/v) glucose; for bacteria expressing rnpA, 1 mM IPTG was added to the medium. + indicates growth with equal numbers of colonies on arabinose and glucose plates; -, no growth;

${ }^{\mathrm{a}}$ Cloned in plasmid pBR322 under control of the inducible pTrc promoter.

${ }^{\mathrm{b}}$ Retarded growth and less colonies on glucose plates $(\sim 10 \%$ of that of arabinose plates), likely revertants.

${ }^{c}$ Cells showed retarded growth.

\section{Restoration of 4.5S RNA maturation in the rnpBC293 background by a compensatory substrate mutation}

From our previous results obtained in the RNA-alone reaction (Busch et al. 2000), it seemed possible that an isosteric $\mathrm{C} 293-\mathrm{G}_{74}$ pair in enzyme-substrate complexes may fully restore activity to that of wild-type complexes. To test if this also holds for the cellular context, we constructed a plasmid-borne 4.5S RNA gene, in which we switched the identity of four consecutive base pairs in the terminal stem region. Expression of the mutated 4.5S RNA was not detrimental to cell viability. The sequence alteration in 4.5S RNA permitted primer annealing exclusively to this 4.5S RNA variant, but not the chromosomally encoded wild-type 4.5S RNA. In addition, two variants with C-to-G exchanges (G "74" or G"75") in the dangling 3'CCC terminus were constructed (Fig. 4A). Primer extension analysis, performed essentially as in Figure 3, indeed revealed full restoration of 4.5S RNA maturation efficacy for the C293 holoenzyme acting on the precursor 4.5S RNA with a $3^{\prime}-\mathrm{G}$ " 74 " CC terminus (Fig. 4, cf. lanes 1,6 and 25,7-9). In contrast, the combination of C292 P RNA and p4.5S RNA 3'-CG“"75"C (Fig. 4, lane 8), although restoring base-pairing, did not reestablish maturation capacity to wild-type levels.

\section{Overexpression of $\boldsymbol{r n p A}$}

We speculated that overexpression of the E. coli RNase P protein might increase the steady-state level of the RNase P holoenzyme and thereby alleviate the processing defects

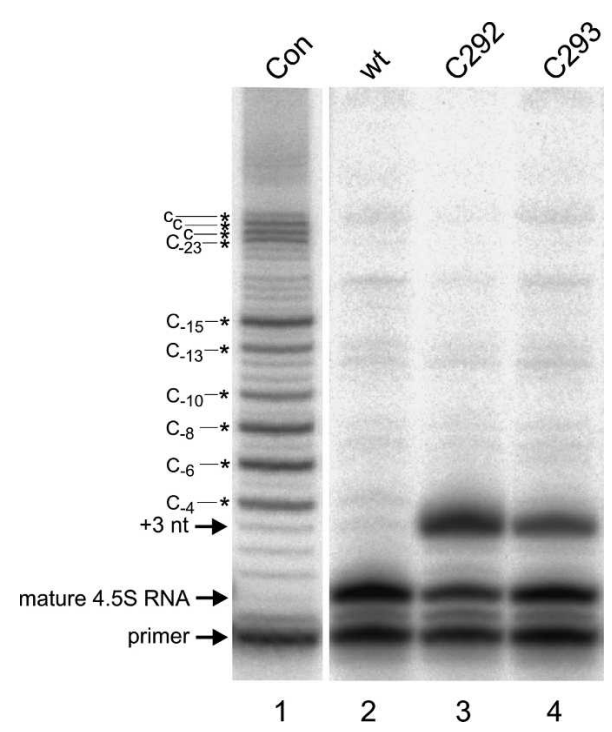

FIGURE 3. Primer extension analysis using a primer specific to $E$. coli 4.5S RNA and total RNA from strain BW expressing pACYC177encoded E. coli rnpBwt (lane 2), rnpBC292 (lane 3), and rnpBC293 (lane 4); Con (lane 1) indicates products of reverse transcription in the presence of ddGTP and using in vitro transcribed precursor $4.5 \mathrm{~S}$ RNA as the template; prominent bands resulted from premature termination of reverse transcription at template $\mathrm{C}$ residues (marked by asterisks); the precursor segment of the in vitro transcribed $\mathrm{p} 4.5 \mathrm{~S}$ RNA had the natural sequence up to residue -23 , but was different beyond this position and carried additional nucleotides for cloning reasons (5'-ggg aga ccg gaa uuc ccC GUU GGU UCU CAA CGC UCU CAA $U_{-1}$, deviations from the wild-type sequence in small letters). Samples were analyzed by $20 \%$ PAGE in the presence of $8 \mathrm{M}$ urea. For growth of BW cells harboring the different plasmids (lanes 2-4) and preparation of total cellular RNA, see Materials and Methods. 
A

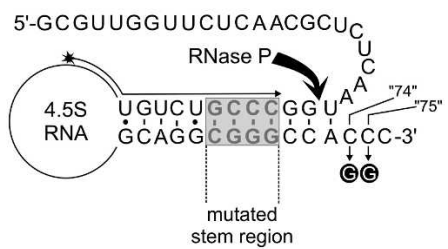

B

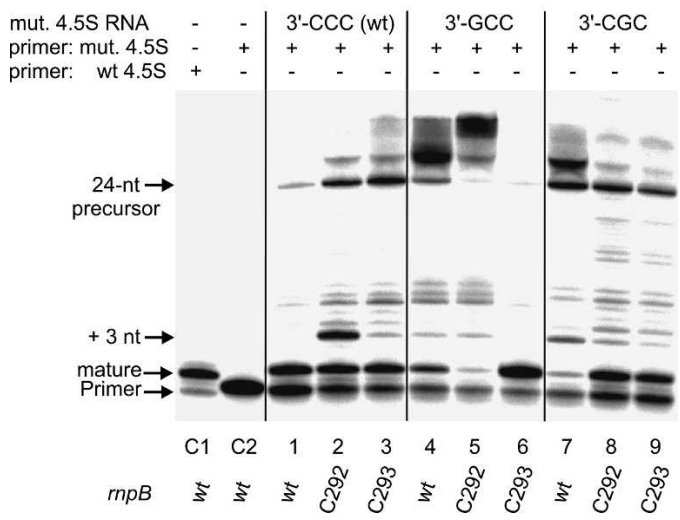

FIGURE 4. Primer extension experiments to analyze processing of pBR322-encoded mutant p4.5S RNA in strain BW expressing $E$. coli $r n p B w t, r n p B C 292$, or $r n p B C 293$. (A) Schematic of the mutant $\mathrm{p} 4.5 \mathrm{~S}$ RNA: The gray-shaded box indicates base-pair exchanges relative to wild-type $4.5 \mathrm{~S}$ RNA, which were introduced to permit specific reverse transcription of mutant $(p) 4.5 \mathrm{~S}$ RNA; two variants carried 3 '-terminal $\mathrm{C}$ to $\mathrm{G}$ exchanges (highlighted) at positions equivalent to nucleotides 74 and 75 of tRNA 3 '-CCA ends; the arrow aligned to the stem depicts the reverse transcription primer, with the terminal asterisk illustrating the $5^{\prime}{ }^{32} \mathrm{P}$-endlabel. (B) Analysis of primer extension products by $20 \%$ PAGE in the presence of $8 \mathrm{M}$ urea. (Lanes C1,C2) Primer extension using total RNA from BW cells grown in the presence of glucose and expressing pACYC177-encoded E. coli rnpBwt, either utilizing the primer for wild-type 4.5S RNA (C1) or mutant 4.5S RNA (C2); the C2 control documents that the primer specific for mutant 4.5S RNA (panel $A$ ) did not prime on wild-type 4.5S RNA. (Lanes 1-9) Primer extension using the primer specific for mutant 4.5S RNA; total RNA was from BW cells grown in the presence of glucose and expressing pACYC177-encoded E. coli rnpBwt (lanes 1,4,7), rnpBC292 (lanes $2,5,8$ ), or $\operatorname{mpBC293}$ (lanes 3,6,9); BW bacteria either expressed the pBR322-encoded mutant p4.5S RNA with the natural 3'-CCC (lanes 1-3), a mutated $3^{\prime}$-GCC (lanes 4-6), or a $3^{\prime}$-CGC (lanes 7-9) terminus. The natural $4.5 \mathrm{~S}$ RNA primary transcript has a $5^{\prime}$ leader of $24 \mathrm{nt}$ (Bothwell et al. 1976; Hsu et al. 1984) as indicated on the left; longer transcripts in lanes $2-5$ and $7-9$ are attributable to transcriptional initiation from the $\beta$-lactamase promoter region still present in our pBR322 plasmid constructs.

caused by the $\operatorname{rnp} B C 292$ and $\operatorname{rnp} B \mathrm{C} 293$ mutant alleles. Indeed, for BW cells expressing $r n p B C 293$, concomitant overexpression of $r p A$ partially restored viability, although growth was retarded relative to cells harboring the rnpBwt allele (Table 2B). In contrast, the defect caused by the C292 mutation could not be cured by overexpressing rnpA. Overexpression of the E. coli RNase P protein (C5) was verified by Western blotting using an antiserum against the E. coli C5 protein (data not shown).

\section{Processing of ptRNA by partially purified holoenzymes assembled in vivo}

We partially purified in vivo assembled holoenzymes by anion exchange chromatography from DW2 cells grown at $43^{\circ} \mathrm{C}$ and either expressing rnpBwt, $r n p B C 292$, or $r n p B C 293$ from plasmid pSP64. Holoenzymes were analyzed by primer extension in the presence of ddGTP (see Materials and Methods) and confirmed to contain $\geq 95 \%$ of the respective mutant RNase P RNA (data not shown). We then tested these holoenzymes for processing of ptRNA $^{\text {Gly }}$ (Fig. 1, termed ptRNAwt in the following) and the two variant substrates thereof, ptRNAG ${ }_{74}$ and ptRNAG ${ }_{75}$, with point mutations in $3^{\prime}-\mathrm{CCA}\left(3^{\prime}-\mathrm{G}_{74} \mathrm{CA}\right.$ and $3^{\prime}-\mathrm{CG}_{75} \mathrm{~A}$ ) to compensate the $\mathrm{C} 292 / 293$ mutations in RNase P RNA. This enabled us to investigate rescue effects in terms of efficiency and cleavage site selection in the RNase $\mathrm{P}$ holoenzyme reaction. Processing assays contained $0.004 \mathrm{~A}_{260}$ units of the partially purified holoenzyme fraction and trace amounts $(<1 \mathrm{nM})$ of radiolabeled substrate. As illustrated in Figure 5, the wild-type holoenzyme substantially miscleaved the two mutant substrates (Fig. 5, panel A). As the wild-type holoenzyme, the C292 and C293 mutant holoenzymes cleaved ptRNAwt to $>95 \%$ at the canonical site. However, the C292 mutation suppressed miscleavage of the ptRNAG $\mathrm{F}_{75}$ substrate (Fig. 5, panel B), as did the C293 mutant holoenzyme when acting on the ptRNAG ${ }_{74}$ substrate (Fig. 5, panel C). These findings were expected based on restoration of the intermolecular base pairs and are in line with results from previous in vitro studies (Kirsebom and Svärd 1994; Svärd et al. 1996; Busch et al. 2000). However, the mutant holoenzymes cleaved ptRNAwt, the only substrate relevant to the in vivo situation, with good efficiency. The purification scheme was identical for DW2 cells expressing the $r n p B w t, \operatorname{rnp} B C 292$, or rnpBC293 alleles, and equal amounts of extract based on absorption at $260 \mathrm{~nm}$ were used in these processing assays. Although we are aware that exact holoenzyme concentrations may not have been identical for all three extracts, good processing efficiencies of the two mutant holoenzymes appeared not fully consistent with their severe in vivo defect. We thus decided to increase the stringency of our processing assay by lowering the $\mathrm{Mg}^{2+}$ concentration to $2 \mathrm{mM}$, assuming that this better mimics the free $\mathrm{Mg}^{2+}$ concentration $(1-2 \mathrm{mM})$ in E. coli cells (Alatossava et al. 1985). For wild-type RNase $P$, the cleavage rate at $10 \mathrm{mM}$ $\mathrm{Mg}^{2+}$ relative to $2 \mathrm{mM} \mathrm{Mg}^{2+}$ was 25 -fold increased $\left(k_{\text {rel }}=\right.$ 25 ), but this difference increased to $\geq 650$-fold for the C292 and C293 mutant enzymes. Thus, the defect of the mutant enzymes was exacerbated at low $\left[\mathrm{Mg}^{2+}\right]$. However, the C293 mutant holoenzyme cleaved the ptRNAG ${ }_{74}$ with the same efficiencies at 2 and $10 \mathrm{mM}\left[\mathrm{Mg}^{2+}\right]$ as the wild-type holoenzyme acting on ptRNAwt (Table 3), demonstrating that the natural $\mathrm{G} 293-\mathrm{C}_{74}$ and the isosteric $\mathrm{C} 293-\mathrm{G}_{74}$ pair are fully exchangeable. In contrast, the $\mathrm{C} 292-\mathrm{G}_{75}$ pair only 


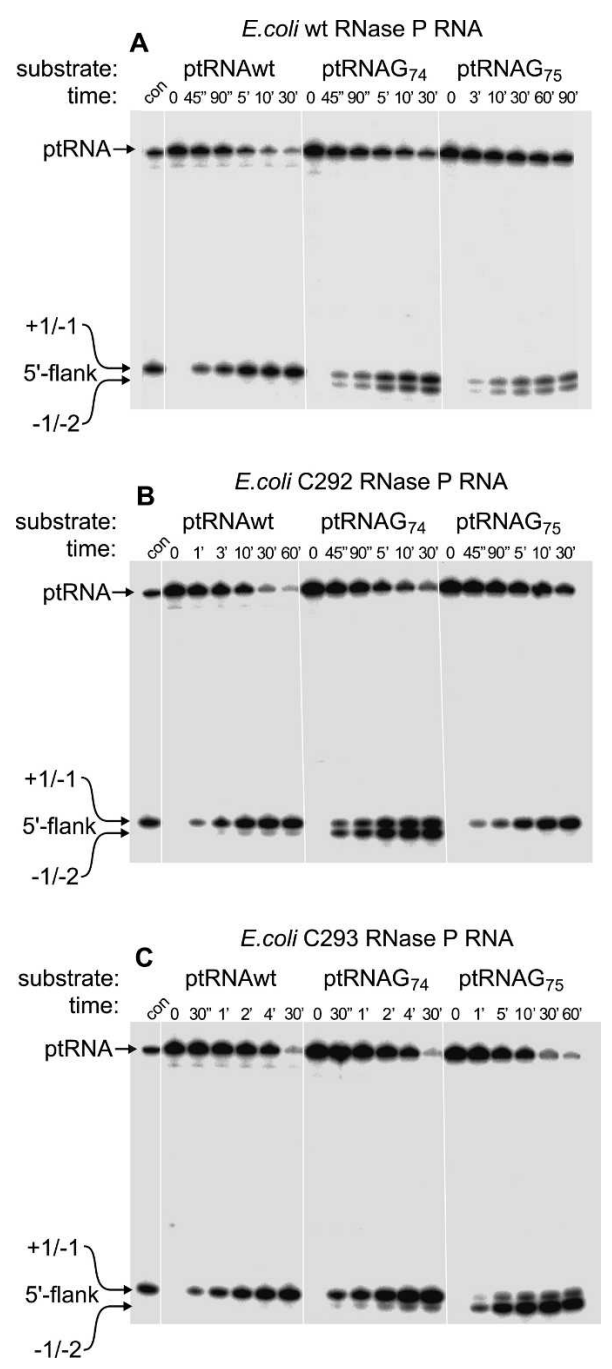

FIGURE 5. Processing assays using RNase $P$ holoenzymes $\left(0.004 \mathrm{~A}_{260}\right.$ units) partially purified from strain DW2 grown at $43^{\circ} \mathrm{C}$ and complemented with E. coli (A) rnpBwt, (B) rnpBC292, and $(C)$ rnpBC293; trace amounts $(<1 \mathrm{nM})$ of $5^{\prime}$-endlabeled ptRNA ${ }^{\text {Gly }}$ (Fig. 1) and variants ptRNAG ${ }_{74}$ and ptRNAG ${ }_{75}$ with single point mutations were used as substrates in buffer A containing $10 \mathrm{mM} \mathrm{Mg}^{2+}$; con indicates trace amounts $(<1 \mathrm{nM})$ of $5^{\prime}$-endlabeled ptRNA ${ }^{\text {Gly }}$ incubated with $5 \mu \mathrm{M}$ E. coli RNase P RNA for $5 \mathrm{sec}$ at $37^{\circ} \mathrm{C}$ in $50 \mathrm{mM}$ PIPES, $0.1 \mathrm{M} \mathrm{Mg}(\mathrm{OAc})_{2}$, and $1 \mathrm{M} \mathrm{NH}_{4} \mathrm{OAc}\left(\mathrm{pH} 7.0\right.$ at $\left.37^{\circ} \mathrm{C}\right) .5^{\prime}-$ cleavage products are indicated on the left (canonical cleavage site at $+1 /-1$, miscleavage at $-1 /-2)$.

showed a partial rescue $\left(k_{\text {rel }}=97\right)$ of the defect, emphasizing the importance of base identity at position 292. Full restoration of function in the presence of the $\mathrm{C} 293-\mathrm{G}_{74}$ pair, but not the $\mathrm{C} 292-\mathrm{G}_{75}$ pair, exactly corresponds with what we have seen for 4.5S RNA maturation in vivo (Fig. 4).

\section{Processing of ptRNA by holoenzymes reconstituted in vitro}

The findings of Table 3 suggested that conditions of $2 \mathrm{mM}$ $\mathrm{Mg}^{2+}$ may better mimic the intracellular conditions than
$10 \mathrm{mM}$. Since enzyme concentrations can be better defined and equalized for in vitro reconstituted enzymes relative to those purified from cells, we further tested in vitro assembled E. coli RNase P holoenzymes under conditions optimized for ribosome function (buffer KN; Materials and Methods) at two different $\mathrm{Mg}^{2+}$ concentrations, 2 and 4.5 $\mathrm{mM}$, and applying multiple turnover kinetics. The wildtype holoenzyme cleaved ptRNAwt with identical rates at 2 and $4.5 \mathrm{mM} \mathrm{Mg}^{2+}$ (Table 4). The mutant enzymes showed cleavage rates reduced by a factor of $\sim 2$ at $4.5 \mathrm{mM} \mathrm{Mg}{ }^{2+}$, but this reduction amounted to 13 - and 24 -fold at $2 \mathrm{mM}$ $\mathrm{Mg}^{2+}$. The pronounced activity drop for the mutant holoenzymes when $\left[\mathrm{Mg}^{2+}\right]$ was only slightly lowered from 4.5 to $2 \mathrm{mM}$, which made it unlikely but did not exclude that a defect in substrate affinity or holoenzyme stability owing to the disruption of the CCA contact might be responsible for this effect. To address the latter possibilities, we tested processing activity under the same conditions but at a fivefold higher holoenzyme concentration (Table 4, lower part). If substrate binding or holoenzyme stability were substantially impaired in reactions catalyzed by the C292/3 mutant enzymes, one would have expected at least a partial activity rescue for the mutant enzymes at this higher enzyme concentration, which, however, was not observed (Table 4).

We then considered the possibility that the C292/3 mutant RNAs have an altered affinity for the protein subunit. This possibility was addressed by testing the activity of holoenzymes reconstituted at increasing excess amounts of RNase P protein over RNase P RNA. However, the dependence of cleavage rate on RNase $\mathrm{P}$ protein concentration showed a very similar saturation behavior for the wild-type and mutant RNase P RNAs, since in all cases activity leveled off above a protein:RNA ratio of 5:1 (Fig. 6). Likewise, the combination of RNase P RNA C293 and substrate ptRNAG ${ }_{74}$ resulted in essentially the same activity profile as for wild-type RNase P RNA acting on ptRNAwt (Fig. 6).

\section{Analysis of RNase P RNA folding equilibria}

At low $\mathrm{Mg}^{2+}$ concentrations, such as $2 \mathrm{mM}$, RNase P RNA folding may be incomplete (Zarrinkar et al. 1996) and particularly sensitive to structural alterations. To test the possibility that differences in RNA folding might have contributed to the in vivo and in vitro phenotypes of the C292 and C293 mutant RNase P RNAs, we performed a native PAGE analysis using the buffer systems applied in our kinetic analyses. To our surprise, the folding equilibria of wild-type, C292, and C293 RNase P RNA displayed clear differences. Without a preincubation step (Fig. 7, lanes 1-3), two major bands appeared, which are interpreted as folding intermediates $\left(\mathrm{I}_{1}\right.$ and $\left.\mathrm{I}_{2}\right)$. For the wild-type RNA, formation of the faster migrating intermediate was favored relative to the two mutant RNAs. 
TABLE 3. Activity of mutant $E$. coli RNase $\mathrm{P}$ holoenzymes purified from strain DW2

\begin{tabular}{|c|c|c|c|c|}
\hline RNase P RNA & substrate & {$\left[\mathrm{Mg}^{2+}\right](\mathrm{mM})$} & $k_{\text {obs }}\left(\min ^{-1}\right)$ & $k_{\text {rel }}$ \\
\hline \multirow[t]{2}{*}{ Wild type } & \multirow[t]{2}{*}{ ptRNA wild type } & 2 & $(15 \pm 0.03) \times 10^{-3}$ & \\
\hline & & 10 & $0.37 \pm 0.03$ & 25 \\
\hline \multirow[t]{2}{*}{ Wild type } & \multirow[t]{2}{*}{ ptRNA G74 } & 2 & n.d. & \\
\hline & & 10 & $0.21 \pm 0.02$ & \\
\hline \multirow[t]{2}{*}{ Wild type } & \multirow[t]{2}{*}{ ptRNA G75 } & 2 & n.d. & \\
\hline & & 10 & $0.047 \pm 0.007$ & \\
\hline \multirow[t]{2}{*}{ C292 } & \multirow[t]{2}{*}{ ptRNA wild type } & 2 & $(17 \pm 3) \times 10^{-5}$ & \\
\hline & & 10 & $0.11 \pm 0.02$ & 647 \\
\hline \multirow[t]{2}{*}{ C292 } & \multirow[t]{2}{*}{ ptRNA G74 } & 2 & n.d. & \\
\hline & & 10 & $0.31 \pm 0.02$ & \\
\hline \multirow[t]{2}{*}{ C292 } & \multirow[t]{2}{*}{ ptRNA G75 } & 2 & $(14.5 \pm 1.5) \times 10^{-4}$ & \\
\hline & & 10 & $0.14 \pm 0.004$ & 97 \\
\hline \multirow[t]{2}{*}{ C293 } & \multirow[t]{2}{*}{ ptRNA wild type } & 2 & $(47 \pm 1) \times 10^{-5}$ & \\
\hline & & 10 & $0.38 \pm 0.04$ & 809 \\
\hline \multirow[t]{2}{*}{ C293 } & \multirow[t]{2}{*}{ ptRNA G74 } & 2 & $(17 \pm 1) \times 10^{-3}$ & \\
\hline & & 10 & $0.42 \pm 0.04$ & 25 \\
\hline \multirow[t]{2}{*}{ C293 } & \multirow{2}{*}{ ptRNA G75 } & 2 & n.d. & \\
\hline & & 10 & $0.13 \pm 0.01$ & \\
\hline
\end{tabular}

Processing was assayed in buffer A: $50 \mathrm{mM}$ Tris- $\mathrm{HCl}, 100 \mathrm{mM} \mathrm{NH}_{4} \mathrm{Cl}, 6 \mathrm{mM}$ DTT, 2 or 10 $\mathrm{mM} \mathrm{Mg}(\mathrm{OAc})_{2}(\mathrm{pH} 7.5), 37^{\circ} \mathrm{C}$; assays contained $0.004 \mathrm{~A}_{260}$ units of partially purified holoenzymes and trace amounts $(<1 \mathrm{nM})$ of $5^{\prime}$-endlabeled substrates. n.d. indicates no cleavage product detectable after $5 \mathrm{~h}$ of incubation; for further details, see Materials and Methods; $k_{\text {rel }}$ is the ratio of $k_{\text {obs }}$ values at 10 versus $2 \mathrm{mM} \mathrm{Mg}^{2+} ; k_{\text {obs }}$ values are based on at least three independent experiments. those supplemented with $10 \mathrm{mM} \mathrm{Mg}^{2+}$. Thus, it remains unclear if $\mathrm{N}_{1}$ and $\mathrm{N}_{2}$ represent identical or different conformers. Under $\mathrm{KN} 2$ conditions, all three RNAs mainly populated the $\mathrm{N}_{2}$ fold, although gel migration of the $\mathrm{C} 293$ RNA was more smeary than that of wild-type and C292 RNA, and some $\mathrm{I}_{1}$ conformer was still visible for the C292 RNA (Fig. 7, lanes 5,8). Upon additional preincubation at $55^{\circ} \mathrm{C}$ (Fig. 7 , lanes 10-12), the differences between the wild-type and mutant RNAs were essentially eliminated.

In buffer $\mathrm{A} 2$ combined with electrophoresis at $2 \mathrm{mM} \mathrm{Mg}^{2+}$, the $\mathrm{N}_{2}$ conformer formed only partially with wildtype RNA (Fig. 7, lanes 7,10, A2), and apparently not at all with the mutant RNAs. This suggests that the KN2 buffer containing spermine and spermidine favors formation of a native fold relative to the A2 buffer. When the native PAGE analysis was conducted with $5^{\prime}$ - instead of $3^{\prime}$-endlabeled RNase P RNA, results were identical to those shown in Figure

In buffers A10 and KN4.5 combined with electrophoresis at $10 \mathrm{mM} \mathrm{Mg}^{2+}$, a preincubation step at $37^{\circ} \mathrm{C}$ (Fig. 7, lanes $4-9$, A10 and KN4.5) led to formation of a more compacted species assumed to represent a native-like conformation (termed $\mathrm{N}_{1}$ ), in accordance with a previous study (Buck et al. 2005). This conformer was in equilibrium with conformer $\mathrm{I}_{2}$, and the protein subunit did not influence this folding equilibrium (Fig. 7, lanes 4-6 versus 7-9). Here, the pattern was essentially identical for the wild-type and C293 mutant RNA, whereas the C292 RNA was still in equilibrium with the $\mathrm{I}_{1}$ conformer (Fig. 7 , lanes 5,8). An additional temperature step at $55^{\circ} \mathrm{C}$ led to almost complete disappearance of the $\mathrm{I}_{1}$ conformer, thus largely eliminating the difference between the C292 and wild-type/C293 RNAs (Fig. 7, lanes 10-12).

In buffer KN2 combined with electrophoresis at $2 \mathrm{mM} \mathrm{Mg}^{2+}$, a band migrating slightly faster than the $\mathrm{I}_{2}$ conformer appeared upon preincubation at $37^{\circ} \mathrm{C}$ or $55^{\circ} \mathrm{C} / 37^{\circ} \mathrm{C}$ (Fig. 7, best visible in lane 1 versus lane $4, \mathrm{KN} 2$ ), which we have termed $\mathrm{N}_{2}$. This band migrated closer to conformer $\mathrm{I}_{2}$ than did conformer $\mathrm{N}_{1}$, but $\mathrm{N}_{2}$ appeared on gels containing $2 \mathrm{mM} \mathrm{Mg}^{2+}$ and $\mathrm{N}_{1}$ on
7 (data not shown).

Although the structural differences between the conformers termed $\mathrm{I}_{1}, \mathrm{I}_{2}, \mathrm{~N}_{1}$, and $\mathrm{N}_{2}$ remain to be characterized, the data in Figure 7 illustrate that the folding equilibria of wild-type and C292/293 mutant RNase P RNAs may differ depending on the particular buffer and
TABLE 4. Cleavage rates for $E$. coli wild-type and mutant RNase $\mathrm{P}$ holoenzymes at low $\mathrm{Mg}^{2+}$ concentrations

\begin{tabular}{lcccc}
\hline RNase P RNA & Enzyme concentration & {$\left[\mathrm{Mg}^{2+}\right]$} & $k_{\text {obs }}$ & $\begin{array}{c}\text { activity } \\
\text { decrease }\end{array}$ \\
\hline Wild type & 10 nM P RNA/50 nM RnpA & 4.5 & $11.2 \pm 0.7$ & - \\
C292 & 10 nM P RNA/50 nM RnpA & 4.5 & $4.8 \pm 0.1$ & 2.33 \\
C293 & 10 nM P RNA/50 nM RnpA & 4.5 & $6.0 \pm 0.6$ & 1.87 \\
& & & & \\
Wild type & 10 nM P RNA/50 nM RnpA & 2.0 & $12.0 \pm 1.4$ & - \\
C292 & 10 nM P RNA/50 nM RnpA & 2.0 & $0.5 \pm 0.06$ & 24.0 \\
C293 & 10 nM P RNA/50 nM RnpA & 2.0 & $0.9 \pm 0.04$ & 13.3 \\
& & & & \\
Wild type & 50 nM P RNA/250 nM RnpA & 2.0 & $21.9 \pm 2.5$ & - \\
C292 & 50 nM P RNA/250 nM RnpA & 2.0 & $0.6 \pm 0.06$ & 36.5 \\
C293 & 50 nM P RNA/250 nM RnpA & 2.0 & $0.6 \pm 0.07$ & 36.5 \\
\hline
\end{tabular}

Processing was assayed in buffer $\mathrm{KN}: 20 \mathrm{mM}$ Hepes $\left(\mathrm{pH} 7.4,37^{\circ} \mathrm{C}\right), 2$ or $4.5 \mathrm{mM} \mathrm{Mg}(\mathrm{OAc})_{2}$, $150 \mathrm{mM} \mathrm{NH}_{4} \mathrm{OAc}, 2 \mathrm{mM}$ spermidine, $0.05 \mathrm{mM}$ spermine, $4 \mathrm{mM} \beta$-mercaptoethanol, and RNase P RNA (P RNA) and E. coli RNase P protein (RnpA) concentrations as indicated; the ptRNAwt concentration was $100 \mathrm{nM} ; k_{\text {obs }}$ is given as nmol substrate converted per nmol of RNase P RNA per min; values are based on at least four independent experiments; activity decrease is defined as the ratio of $k_{\text {obs }}$ obtained with wild-type versus mutant holoenzyme under the respective conditions. 


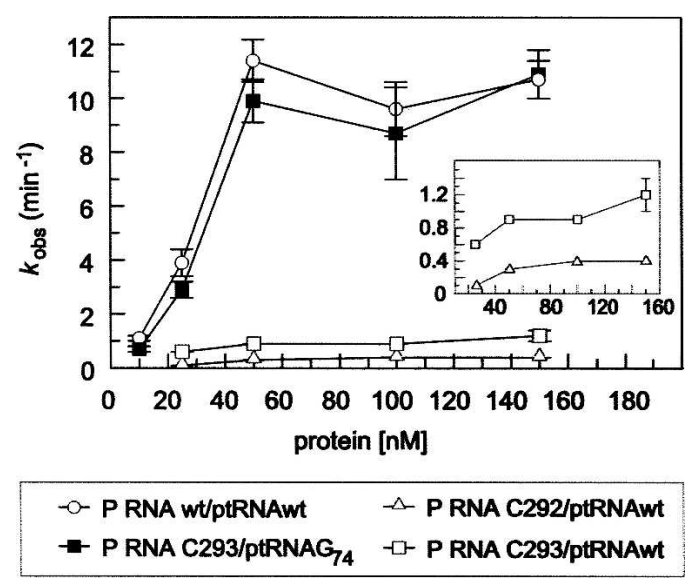

FIGURE 6. Activity of wild-type and mutant holoenzymes reconstituted at different RNase $\mathrm{P}$ protein/RNA ratios and acting on ptRNAwt; in addition, the activity profile for cleavage of ptRNAG ${ }_{74}$ by the $\mathrm{C} 293$ mutant holoenzyme is shown. Assay conditions were $20 \mathrm{mM}$ Hepes $\left(\mathrm{pH} 7.4,37^{\circ} \mathrm{C}\right), 2 \mathrm{mM} \mathrm{Mg}(\mathrm{OAc})_{2}, 150 \mathrm{mM} \mathrm{NH}_{4} \mathrm{OAc}$, $2 \mathrm{mM}$ spermidine, $0.05 \mathrm{mM}$ spermine, and $4 \mathrm{mM} \beta$-mercaptoethanol. RNase P RNA concentration was kept constant at $10 \mathrm{nM}$, and substrate concentrations were $100 \mathrm{nM} ; k_{\text {obs }}$ is given as nmol substrate converted per nmol of RNase P RNA per min; values are based on at least four independent experiments. The inset is a magnification of the lowest activity curves. P RNA, E. coli RNase P RNA.

preincubation conditions. It thus remains a possibility that the folding properties of the two mutant RNase P RNAs contributed to their defect in vivo. Unlike a recent study (Buck et al. 2005), we did not observe major effects of the protein component on RNase P RNA folding equilibria. This may be related to the fact that stabilization of the RNA fold by the protein was analyzed at $<1 \mathrm{mM} \mathrm{Mg}^{2+}$ (Buck et al. 2005).

\section{DISCUSSION}

We have assessed the role of the CCA interaction in vivo by complementation analyses in two RNase P mutant strains. In both strains (DW2 and BW), $r n p B C 292$ and $r n p B C 293$ alleles encoding P RNA variants with a disrupted CCA interaction impaired or abrogated cell vitality (Tables 1,2 ). Particularly, the phenotypes in strain BW (Table 2) demonstrate that base-pairing of G292 and G293 with $\mathrm{C}_{74}$ and $\mathrm{C}_{75}$ of RNase $\mathrm{P}$ substrates is essential in vivo, and its disruption is not compensated by the presence of the RNase P protein subunit in holoenzyme complexes. The BW strain also reconciles in vivo phenotype with kinetic data obtained in vitro: RNase P RNA C292 was more defective than the C293 variant in RNA alone (Busch et al. 2000 ) as well as in holoenzyme reactions using ptRNAwt as the substrate (Table 4; Fig. 6). In agreement, concomitant $r n p A$ overexpression slightly improved viability of BW cells expressing $r n p B C 293$, but not $r n p B C 292$ (Table 2B).

The molecular basis of increased viability owing to $\operatorname{rnp} A$ overexpression in BW bacteria expressing $r p p B C 293$ is not fully clear yet. We think it likely that higher levels of RNase $\mathrm{P}$ protein lead to increased steady-state levels of holoenzyme, either by shifting the equilibrium between free RNase $\mathrm{P}$ subunits and holoenzyme toward holoenzyme or by a mechanism that couples RNase P RNA and protein expression, according to which increased RNase $\mathrm{P}$ protein levels would entail a corresponding increase in the level of the RNA subunit. The latter possibility has been discussed in the context of a study on RNase P RNA metabolism in E. coli (Kim et al. 2005). E. coli $r p p B$ primary transcripts can undergo either $3^{\prime}$-end maturation or oligoadenylation resulting in degradation. A knockout of poly(A) polymerase $(p c n B)$, which blocks the degradation pathway, thus increased the level of 3 '-precursor RNase P RNA. However, this was not associated with a concomitant increase in the level of mature RNase P RNA, leading to the proposal that mature RNase P RNA may only stably accumulate when complexed with its protein subunit (Kim et al. 2005).

Previous in vitro studies, focusing on the E. coli RNAalone reaction, have indicated that the CCA contact increases substrate affinity (Hardt et al. 1995; Oh et al. 1998;

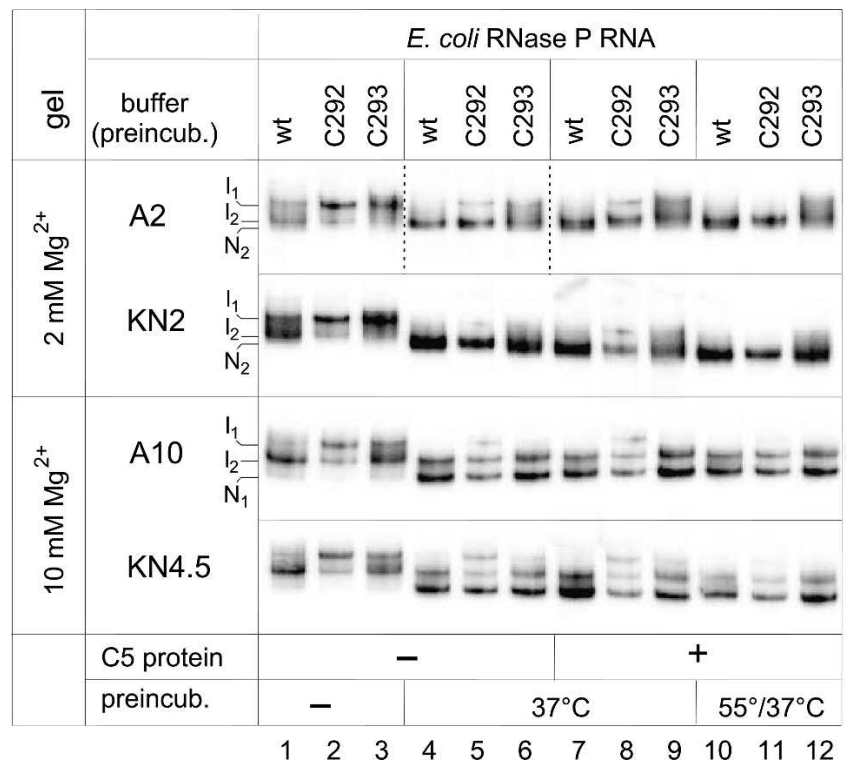

FIGURE 7. Analysis of folding equilibria for wild-type and C292/ C293 mutant E. coli RNase P RNAs by native PAGE. RNAs ( $50 \mathrm{fmol}$, $3^{\prime}$ endlabeled) were preincubated either in buffer A containing $2 \mathrm{mM}$ (A2) or $10 \mathrm{mM}(A 10) \mathrm{Mg}^{2+}$, or in buffer $\mathrm{KN}$ containing $2 \mathrm{mM}$ (KN2) or $4.5 \mathrm{mM}(\mathrm{KN} 4.5) \mathrm{Mg}^{2+}$ in a volume of $4-5 \mu \mathrm{L}$ (for buffer A and $\mathrm{KN}$ compositions, see Materials and Methods). (Lanes 1-3) No preincubation (kept at $4^{\circ} \mathrm{C}$ ); (lanes 4-6) preincubation of RNase P RNAs for $70 \mathrm{~min}$ at $37^{\circ} \mathrm{C}$; (lanes 7-9) preincubation of RNase P RNAs for 55 min at $37^{\circ} \mathrm{C}$, addition of $1 \mu \mathrm{L} \mathrm{E}$. coli C5 protein (final concentration $50 \mathrm{nM}$ ) and further incubation for $15 \mathrm{~min}$ at $37^{\circ} \mathrm{C}$; (lanes 10-12) as in lanes 7-9, but preincubation of RNase P RNAs for 5 min at $55^{\circ} \mathrm{C}$ and $50 \mathrm{~min} 37^{\circ} \mathrm{C}$. Samples were run on $11.25 \%$ polyacrylamide gels in $1 \times$ THE buffer supplemented with $100 \mathrm{mM} \mathrm{NH}_{4} \mathrm{OAc}$ and either $2 \mathrm{mM}$ $(\mathrm{A} 2, \mathrm{KN} 2)$ or $10 \mathrm{mM}(\mathrm{A} 10, \mathrm{KN} 4.5) \mathrm{MgCl}_{2}$. The dashed lines confining lanes 4-6 in panel $A 2$ indicate that these lanes were taken from a different gel. 
Busch et al. 2000) and supports selection of the correct cleavage site (Kirsebom and Svärd 1994) as well as catalysis (Oh et al. 1998; Busch et al. 2000; Brännvall et al. 2003). Based on the data presented here, we infer that disruption of the CCA interaction primarily causes a defect in the binding of catalytically important $\mathrm{Mg}^{2+}$ under in vivo conditions, based on the following argumentation: The activity of mutant holoenzymes, either assembled in vivo (Table 3) or in vitro (Table 4), was reduced only about two- to threefold relative to the wild-type holoenzyme at $\mathrm{Mg}^{2+}$ concentrations of $4.5-10 \mathrm{mM}$. However, a shift from 10 to $2 \mathrm{mM}$ $\mathrm{Mg}^{2+}$ reduced the rate of ptRNAwt cleavage 25-fold for the wild-type holoenzyme, but 650- and 810-fold for the C292 and C293 mutant enzymes (Table 3). We are aware that these rate differences may include contributions from deviating folding properties of the mutant RNAs in buffer A containing $2 \mathrm{mM} \mathrm{Mg}^{2+}$ (Fig. 7, panel A2). Since folding equilibria of the wild-type and mutant RNase P RNAs were much more similar in the KN buffer system (Fig. 7), the results shown in Table 4 are thus likely to be most meaningful. Nevertheless, a similar trend was observed: The shift from 4.5 to $2.0 \mathrm{mM} \mathrm{Mg}^{2+}$ had a negligible effect on cleavage by the wild-type enzyme but reduced the cleavage rate 13- and 24-fold for the C293 and C292 mutant enzymes, respectively (Table 4). Such pronounced effects on cleavage rate in response to a shift from 4.5 to $2 \mathrm{mM} \mathrm{Mg}^{2+}$ are hard to explain by reasons other than a catalytic defect, although contributions from decreased substrate affinity or reduced affinity of the protein subunit cannot be excluded. The latter possibility might be suggested by the finding that the RNase P protein-RNA complex is stabilized by addition of substrate in the Bacillus subtilis system (Day-Storms et al. 2004). To test the possibility of decreased substrate affinity as the cause of low mutant enzyme activity at $2 \mathrm{mM} \mathrm{Mg}^{2+}$, we increased the holoenzyme concentration by a factor of 5 (Table 4). However, this only increased the cleavage rate for the wild-type enzyme but not for the mutant holoenzymes, suggesting that decreased substrate affinity owing to disruption of the CCA contact is not a major cause for the defect of the mutant holoenzymes. Likewise, in the RNase P protein titration experiment (Fig. 6), activity essentially saturated at a protein/RNA ratio of 5:1 for the wild-type and mutant holoenzymes acting on ptRNAwt, thus providing no evidence for a major protein binding defect of the mutant RNase P RNAs. Finally, this is in line with the fact that we enriched the wild-type and mutant holoenzymes with comparable yields from cell extracts by anion exchange chromatography (Table 3 ).

Another potential defect of the C292 and C293 mutant RNAs in vivo could be aberrant folding leading to increased degradation. However, the mutant enzymes partially purified from strain DW2 had similar activities as the wild-type enzyme at $10 \mathrm{mM} \mathrm{Mg}{ }^{2+}$ (Table 3). The same amounts of extract based on absorption at $260 \mathrm{~nm}$ were used in these processing assays, providing no evidence for altered RNase
P levels in bacteria expressing rnpBC292 and $r n p B C 293$. Likewise, wild-type-like maturation of plasmid-encoded 4.5S RNA by the C293 holoenzyme when base-pairing is restored by a compensatory mutation in the $3^{\prime}$ end of this substrate (Fig. 4) argues against substantial degradation of the mutant RNA.

On the basis of the data shown in Figure 7, it remains a possibility that differences in the folding equilibria of the wild-type versus mutant RNase P RNAs may have contributed to the mutant defects in vivo. The sensitivity of RNA folding toward point mutations in loop L15 might also provide a clue as to why the relative phenotypes of the C292 and C293 mutant RNAs deviated in strain DW2 grown at $43^{\circ} \mathrm{C}$ compared with strain $\mathrm{BW}$ grown at $37^{\circ} \mathrm{C}$. In any case, the results of Figure 7 point to the sensitivity of RNase P RNA folding to structural changes as small as point mutations, particularly in low $\mathrm{Mg}^{2+}$ buffers. This seems surprising in view of the highly dynamic nature of the loop L15 region, as inferred from biochemical experiments (Ciesiolka et al. 1994; Brännvall et al. 2003) and evident in the crystal structure of Thermotoga maritima RNase P RNA (Torres-Larios et al. 2005). On the other hand, the dynamic nature of this region might increase its propensity to interfere with folding of other structural elements in the molecule. It will be interesting to see if mutations in other RNase P RNA elements may be able to exert similarly pronounced effects on folding at low $\mathrm{Mg}^{2+}$ concentrations.

The mutant holoenzymes cleaved the ptRNAwt substrate predominantly at the canonical site (Fig. 5), which also pertained to conditions of $2 \mathrm{mM} \mathrm{Mg}^{2+}$ (data not shown). Only the C292 enzyme showed some increase in miscleavage $(<5 \%)$ (Fig. 5). A low extent of miscleavage is consistent with a previous study (Oh et al. 1998) analyzing processing of $B$. subtilis ptRNA ${ }^{\text {Asp }}$ with CCA mutations by the E. coli wild-type holoenzyme. Oh et al. (1998) did not observe aberrant cleavage under any set of conditions. The ptRNA $^{\text {Asp }}$, as the ptRNA ${ }^{\text {Gly }}$ used here, forms a canonical 7bp acceptor stem and lacks any potential for extended acceptor stem base-pairing involving nucleotide $-1 /+73$. Miscleavage in vivo may yet be increased for some ptRNAs, such as E. coli pSu1, which can form a C-1:G73 base pair (Svärd et al. 1996). In vitro processing of the latter substrate by reconstituted $E$. coli mutant holoenzymes gave substantial miscleavage (27\% for the C293, 55\% for the C292 variant) (Svärd et al. 1996). Thus, substantial aberrant cleavage of some cellular ptRNAs cannot be excluded and might contribute to the mutant phenotypes, particularly to that of $\operatorname{rnpB292}$ in strain BW (Table 2).

Our results rationalize some previous in vitro data. For example, E. coli RNase P-catalyzed cleavage of ptRNA substrates with single nucleotide substitutions in CCA or a CCA deletion suggested that the protein subunit suppresses the binding defect for catalytic $\mathrm{Mg}^{2+}$ (Oh et al. 1998). However, these experiments were done at $100 \mathrm{mM}$ 
$\mathrm{Mg}^{2+}$, conditions that mask the defect, as illustrated by the sharp activity differences we obtained at 2 versus $4.5 \mathrm{mM}$ $\mathrm{Mg}^{2+}$ (Table 4).

The $\mathrm{P} 15 / \mathrm{L} 15 / \mathrm{P} 16$ region is a central $\mathrm{Me}^{2+}$ binding module in the active site of RNase P RNA (Kufel and Kirsebom, 1998; Altman and Kirsebom 1999; Brännvall et al. 2003). Binding of tRNA CCA ends suppresses, in vitro and in vivo, prominent $\mathrm{Pb}^{2+}$ hydrolysis at two locations in the L15 loop (sites III and V) and creates a new prominent $\mathrm{Pb}^{2+}$ hydrolysis site (IVb) nearby (Ciesiolka et al. 1994; Lindell et al. 2005). This indicates a structural rearrangement of the P15/L15/P16 region upon formation of the G292- $\mathrm{C}_{75}$ and $\mathrm{G} 293-\mathrm{C}_{74}$ intermolecular base pairs. The P15/L15/P16 module is also predicted to undergo a substantial conformational rearrangement upon substrate docking to the active site based on the recent crystal structure of $T$. maritima RNase P RNA (Torres-Larios et al. 2005). These observations combined with our findings presented here accentuate the need to include enzymesubstrate complexes in future structural analyses of RNase $\mathrm{P}$ in order to understand the catalytic mechanism of this ribozyme. Finally, our study suggests that activity tests of bacterial RNase $\mathrm{P}$ holoenzymes are better performed at $\mathrm{Mg}^{2+}$ concentrations $<10 \mathrm{mM}$ in order to be able to draw conclusions that are biologically relevant.

\section{MATERIALS AND METHODS}

\section{Bacteria}

E. coli strains DW2/pDW160 (Waugh and Pace 1990) and BW (this study) were used for complementation studies.

\section{Complementation studies in strain DW2}

For strain DW2/pDW160 (named DW2 in the following), complementing $r n p B$ genes were under control of the native E. coli $r n p B$ promoter and cloned in plasmid pSP64 as described (Hardt and Hartmann 1996). The pSP64 derivative carrying E. coli rnpB (pSP64 E. coli $r n p B$ ) served as template to introduce the point mutations C292 or C293 by the site-directed DpnI method according to the manual provided with the QuikChange XL Site-Directed mutagenesis Kit (Stratagene), using the primer pair 5'-GTA CTG AAC CCG CGT AGG CTG CTT GAGC and 5'-GCT CAA GCA GCC TAC GCG GGT TCA GTA C for the C292 mutation, and 5'-GTA CTG AAC CCG GCT AGG CTG CTT GAG C and 5' -GCT CAA GCA GCC TAG CCG GGT TCA GTA C for the $\mathrm{C} 293$ mutation (sites of mutation underlined). Recombinant $r n p B$-coding pSP64 derivatives (10 ng) were introduced into DW2 by electroporation, using a Biorad GenePulser $(1.8 \mathrm{kV} ; 5 \mathrm{msec}$, $50 \mu \mathrm{F}, 100 \Omega$ ). After the pulse, $1 \mathrm{~mL}$ SOC medium (per liter: $20 \mathrm{~g}$ peptone, $5 \mathrm{~g}$ yeast extract, $0.6 \mathrm{~g} \mathrm{NaCl}, 0.17 \mathrm{~g} \mathrm{KCl}, 20 \mathrm{mM}$ glucose, $10 \mathrm{mM} \mathrm{MgCl}_{2}, 10 \mathrm{mM} \mathrm{MgSO}_{4}$ at $\mathrm{pH}$ 7.5) was added, and cells were shaken for $1 \mathrm{~h}$ at $30^{\circ} \mathrm{C}$. Appropriate dilutions of cell suspensions were plated on two LB agar plates, containing $100 \mu \mathrm{g} / \mathrm{mL}$ ampicillin and $30 \mu \mathrm{g} / \mathrm{mL}$ chloramphenicol. The two sets of plates were incubated in parallel at $30^{\circ} \mathrm{C}$ or $43^{\circ} \mathrm{C}$, respectively, for $20-40 \mathrm{~h}$.

\section{Construction of $r n p B$ mutant strain BW}

Construction of strain BW followed the strategy described by Roux et al. (2005). The so-called catRExBAD cassette (Fig. 2A) was amplified from strain TG1 cat-AraC (Roux et al. 2005) using primers 135 (5'-CTT CAG CGT ATT GAC CAG CAT AGG TAC GTT GGA CGA AGC ATT CCG CGG GCT TGC ATA ATG TGC CTG TC; the underlined sequence is identical to the region upstream of the E. coli rnpB promoter) and 134 (5'-GTC TCC CCC GAA GAG GAC GAC GAC GAA GCG GCG ACT GTC TGG TCA GCT TCT ATG GAG AAA CAG TAG AGA GTT GC; the underlined sequence is complementary to E. coli $r n p B$, corresponding to nucleotides 1-50 of mature RNase P RNA). Initially, we could isolate a recombinant strain, which had the $5^{\prime}$ end of the described catRExBAD cassette successfully recombined within the $5^{\prime}$-rnpB promoter upstream region, but the $3^{\prime}$ boundary was altered. This strain was used to amplify a 326-bp fragment, containing the $5^{\prime}$ boundary, with primers $5^{\prime}-r n p B$ ext $\left(5^{\prime}\right.$-CGA TTG GTG TCG CAA ACG TGG) and $3^{\prime}$-catRExBADveri (5' -CGC AAG GCG ACA AGG TGC TG). The E. coli $r n p B$ gene was amplified from E. coli K12 with primers $3^{\prime}$-rnpB (5'-AGG TGA AAC TGA CCG ATA AGC C) and $5^{\prime}-r n p B$ ( $5^{\prime}$-GAA GCT GAC CAG ACA GTC GC). This $r n p B$ fragment and the 326-bp fragment with $E$. coli $r m p B$ upstream sequence were combined with the catRExBAD cassette by overlapping PCR. The resulting PCR product was purified by agarose gel electrophoresis and transformed into E. coli MG1655 bacteria carrying pKD46 (temperature-sensitive helper plasmid expressing the $\lambda$ red recombinase system) (Datsenko and Wanner 2000). For this purpose, MG1655/pKD46 cells were grown at $28^{\circ} \mathrm{C}$ to an $\mathrm{OD}_{578}$ of 0.15 , followed by adjusting cultures to $10 \mathrm{mM}$ arabinose to induce the $\lambda$ red genes. Induced bacteria were then further grown to an $\mathrm{OD}_{578}$ of 0.6 and made electro-competent by 100 -fold concentration and three washing steps with ice-cold $10 \%$ glycerol. Electroporation was performed with a Biorad Gene Pulser in 1-mm cuvettes (1.8 $\mathrm{kV}, 200 \mu \mathrm{F}, 25 \Omega$ ) using $40 \mu \mathrm{L}$ competent cells and 100-200 ng purified PCR fragment. Pulsed cells were added to $1 \mathrm{~mL}$ SOC medium supplemented with $10 \mathrm{mM}$ arabinose, shaken for $1 \mathrm{~h}$ at $37^{\circ} \mathrm{C}$ and $900 \mathrm{rpm}$ (Eppendorf Thermomixer comfort), and then plated and incubated at $37^{\circ} \mathrm{C}$ on LB agar plates containing $25 \mu \mathrm{g} /$ $\mathrm{mL}$ chloramphenicol and $10 \mathrm{mM}$ arabinose. Clones were analyzed by PCR for correct $5^{\prime}$ and $3^{\prime}$ boundaries of the integrated catRExBAD cassette and screened for ampicillin sensitivity to test for loss of the temperature-sensitive helper plasmid pKD46. The following primers were used to scrutinize correct insertion and sequence of the integrated cassette:

primer 195 (3' AraC): 5'-GCA TGG AAG CGA TTA ACG AGT CGC

primer 194 (5' AraC): 5'-GCG ACT CGT TAA TCG CTT CCA TGC

primer 193 (5' E. coli rmpB promoter -58): 5'-CAC GTA ATA TCG CCG CGA CAC TGG

primer 158 (ext veri 3' rnpB): 5'-GTG AAA CTG ACC GAT AAG CCG C

primer 157 (5' ext veri $r p p B$ ): 5'-TGC AGG AGC TGC GGG TGG

primer 136 (RExBADveri 5'): 5'-CGG CGT CAC ACT TTG CTA TGC C

primer 138 (catBADveri3'): 5'-CGC AAG GCG ACA AGG TGC TG 
primer 49 (ecRevT3): 5'-CTC ACT GGC TCA AGC AGC CT primer $186(\mathrm{Ecm} 1$ up +350): 5'-CAT TCG CGT CGC TTG TGA TGT C

primer $183\left(\mathrm{Ecm} 1+3503^{\prime}\right): 5^{\prime}$-CGC CGG AAC GGT TTA TTA CGT AC

Integrity of the $5^{\prime}$ boundary was checked by primer combinations $157 / 138$ and $138 / 186$, and that of the $3^{\prime}$ boundary by the combinations $136 / 158$ and $136 / 183$; the absence of the native $\operatorname{rnp} B$ promoter region was verified with the primer pair 193/49, which produced a PCR fragment with genomic DNA from strain MG1655 (the original strain), but not with DNA from correct recombinants. Primer pairs $194 / 49$ and 195/157 were used to amplify the inserted cassette in roughly two halves (upstream and downstream from $a r a C$ ) (see Fig. 2A) for verification by sequencing. Verified recombinant bacteria were named strain BW.

\section{Construction of the low copy plasmid pACYC177 E. coli rnpB}

To construct the derivatives of low copy plasmid pACYC177 encoding E. coli rnpBwt, $r n p B C 292$, and $r n p B C 293$, plasmids pSP64 E. coli $r n p B w t, r n p B C 292$, or $r n p B C 293$ were digested with NheI and HindIII and the fragments carrying the different E. coli rnpB alleles were inserted into pACYC177 cut with HindIII and NheI.

\section{Complementation studies in strain BW}

Derivatives of pACYC177 or pBR322 were introduced into strain BW by electroporation as described for DW2 bacteria. However, after the pulse, $1 \mathrm{~mL}$ SOC medium supplemented with $10 \mathrm{mM}$ arabinose was added and cells were incubated for $1 \mathrm{~h}$ at $37^{\circ} \mathrm{C}$; cells were twice pelleted by centrifugation and resuspended in $1 \mathrm{~mL} \mathrm{LB}$ medium. After the second washing step, cells were plated in appropriate dilutions on LB agar plates containing $100 \mu \mathrm{g} / \mathrm{mL}$ ampicillin, $25 \mu \mathrm{g} / \mathrm{mL}$ chloramphenicol, and either $10 \mathrm{mM}$ arabinose or $0.5 \%(\mathrm{w} / \mathrm{v})$ glucose; $10 \mu \mathrm{g} / \mathrm{mL}$ tetracycline was added if BW bacteria additionally harbored pBR322 derivatives expressing E. coli rnpA or mutant 4.5S RNA; 1 mM IPTG was further added for induction of plasmid-encoded $r n p A$. For growth curve measurements, an overnight culture grown at $37^{\circ} \mathrm{C}$ in $\mathrm{LB}$ medium containing $10 \mathrm{mM}$ arabinose and respective antibiotics (see above) was washed twice as described above, and then $50 \mathrm{~mL}$ volumes of $\mathrm{LB}$ were inoculated to an $\mathrm{OD}_{578}$ of $0.05-0.1$, either supplemented with $10 \mathrm{mM}$ arabinose or $0.5 \%$ glucose, followed by growth curve monitoring at $37^{\circ} \mathrm{C}$ and $180 \mathrm{rpm}$ (Incubator GFL 3033).

\section{Construction of pBR322 derivatives for expression of $E$. coli rnpA}

To put E. coli rnpA under the control of the inducible pTrcpromoter (Amann et al. 1988), the $r n p A$ gene was amplified with primers 5'-AGA CCA TGG TTA AGC TCG CAT TTC C (introducing an NcoI site, underlined, at the $5^{\prime}$ end of $\left.r m p A\right)$ and $5^{\prime}$ ATC TCT AGA GTC AGG ACC CGC GAG CCA (introducing an $\mathrm{XbaI}$ site, underlined, at the $3^{\prime}$ end of $\left.r m p A\right)$. The E. coli rnpA fragment was digested with $\mathrm{NcoI}$ and $\mathrm{XbaI}$, and ligated into pTrc99a (Amann et al. 1988) also linearized with NcoI and XbaI, resulting in plasmid pTrc99a E. coli rnpA. This plasmid was unsuitable for our complementation studies, because it encodes an ampicillin resistance as plasmid pACYC177; also, the high copy number of pTrc99a E. coli $r n p A$ would have potentially increased an imbalance between $\operatorname{rnp} A$ expression and that of $r m p B$ genes encoded on the low copy plasmid pACYC177. Therefore, we amplified the $r n p A$ gene including the $p \operatorname{Trc}$ promoter and the rrnBt1t2 terminator from $\mathrm{p} \operatorname{Trc} 99 \mathrm{a}$ E. coli $r n p A$, using the primers 5'-CAC ATG CAT GCA AAA AGG CCA TCC GTC AGG (introducing an Mph1103 I site, underlined) and 5'-ACA ATC GAT TCA ATT GCG CCG ACA TCA TAA CGG (introducing a MunI site, underlined) and ligated the fragment into pBR322 cut with PstI and EcoRI. Digestion of pBR322 with PstI and EcoRI (ends compatible with those of Mph11103 I and MunI, respectively) destroyed the ampicillin resistance, only leaving the tetracycline resistance.

\section{Construction of pBR322 encoding mutated 4.5S RNAs}

The chromosomal region of E. coli $\mathrm{K} 12$ harboring the bicistronic transcription unit of $f f s$ (encoding 4.5S RNA) and $y b a A$, including the native promoter upstream of ffs as well as $100 \mathrm{bp}$ downstream from $y b a A$, was amplified and cloned into pBR322. During PCR amplification, we already altered the terminal stem region by inversion of $4 \mathrm{bp}$ within the stem structure (Fig. 4A) for specific reverse transcriptase priming in order to be able to distinguish native from plasmid-encoded 4.5S RNA. The promoter region and the 5 ' end of ffs were amplified using primers 5'-ACA GAA TTC AGC ATA ATC TGG AAA AAC GCC C (introducing an EcoRI site, underlined) and $5^{\prime}$-CCA ACA GAC GGG CCA TTG AGA GCG TTG AGA ACC (5'-terminal 4.5S RNA stem mutations in bold); the $5^{\prime}$ portion of the $f f s$ gene was amplified with the primer pair 5'-CTC AAT GGC CCG TCT GTT GGT TCT CCC GCA AC and 5'-TCT CTG CAG TAA CGC GTC ATC TGC CTT GGC (introducing MluI and PstI sites, underlined). These two fragments were combined by overlap extension PCR, cut with EcoRI and PstI, followed by ligation into pBR322 cut with the same enzymes. The $3^{\prime}$ half of $f f s$ was amplified with primer pair $5^{\prime}$-CTC AAT GGC CCG TCT GTT GGT TCT CCC GCA AC and $5^{\prime}$-TGG CCC GCC TGC CAG CTA CAT CCC GG ( $3^{\prime}$-terminal stem mutations in bold). The chromosomal region spanning the $3^{\prime}$ terminal $19 \mathrm{bp}$ of $f f s$ and the $y b a A$ cistron was amplified using forward primer 5'-GCT GGC AGG CGG GCC ACC CAT TTC TGC CTC CCA CCG TTT C and reverse primer 5'-CAC CTG CAG CAA GGC ATT ACC GAA AGA AG. To further introduce point mutations into the $3^{\prime}$-CCC end of 4.5S RNA, the same PCR reaction was performed except that $5^{\prime}$-GCT GGC AGG CGG GCC

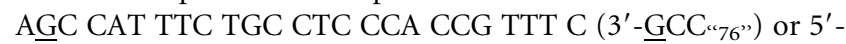
GCT GGC AGG CGG GCC ACG CAT TTC TGC CTC CCA CCG TTT C (3'-CGC " $\left.76^{\prime}\right)$ was used as the forward primer. The latter three amplification products were combined with the PCR fragment harboring the $3^{\prime}$ half of ffs (see above) by overlap extension PCR. The resulting product was then cut with PstI/MluI and ligated into the pBR322 derivative containing the promoter and $5^{\prime}$ half of ffs and cut with the same restriction enzymes.

\section{In vitro transcription and $5^{\prime}$ and $3^{\prime}$ endlabeling}

Runoff transcription with bacteriophage T7 RNA polymerase as well as $5^{\prime}$ and $3^{\prime}$ endlabling were performed essentially as described (Heide et al. 1999; Busch et al. 2000). The ptRNA ${ }^{\text {Gly }}$ substrate (Fig. 1) was transcribed from plasmid pSBpt3' $\mathrm{HH}$ (Busch et al. 2000). Mutations G74 and G75 were introduced by 
the site-directed DpnI mutagenesis method according to the manual provided with the QuikChange XL Site-Directed Mutagenesis Kit (Stratagene); the primer pair for introduction of the $\mathrm{G}_{74}$ mutation was 5'-CCG TCT CCC GCT GCA GTC ACC GGA TGT GC and 5'-GCA CAT CCG GTG ACT GCA GCG GGA GAC GG; for introduction of the $\mathrm{G}_{75}$ mutation, 5'-CCG TCT CCC GCT CGA GTC ACC GGA TGT GC and 5'-GCA CAT CCG GTG ACT CGA GCG GGA GAC GG were used (sites of mutation underlined). Precursor 4.5S RNA was transcribed from a PCR template under control of the T7 promoter; the PCR template was amplified from plasmid pT7-4.5S (constructed and kindly provided by Norman R. Pace, University of Colorado, Boulder, CO), a derivative of plasmid pT71 (Tabor and Richardson 1985) encoding E. coli $4.5 \mathrm{~S}$ RNA with 23 nt of its natural $5^{\prime}$-flanking sequence and 17 additional $5^{\prime}$-flanking nucleotides; the 4.5S RNA precursor transcript carried an additional AUA at the $3^{\prime}$ end in comparison with natural mature 4.5S RNA (Peck-Miller and Altman 1991); PCR primers were 5'-CCA GAA TTC GAA ATT AAT ACG ACT CAC TAT A (T7 promoter underlined) and 5'TAT GGG TGG GGG CCC TGC CAG CTA. E. coli RNase P RNA and C292/3 mutant variants were synthesized as described previously (Busch et al. 2000).

\section{RNA isolation for primer extension analysis}

DW2 bacteria harboring derivatives of plasmid pSP64 were grown at $30^{\circ} \mathrm{C}$ overnight in LB containing $100 \mu \mathrm{g} / \mathrm{mL}$ ampicillin and 30 $\mu \mathrm{g} / \mathrm{mL}$ chloramphenicol. On the next morning, the same culture was incubated for $2 \mathrm{~h}$ at $43^{\circ} \mathrm{C}$, followed by inoculation of fresh medium (100 or $250 \mathrm{~mL}$ ) to a starting $\mathrm{OD}_{578}$ of $0.05-0.1$, and further cultivation at $43^{\circ} \mathrm{C}$ until cell density reached an $\mathrm{OD}_{578}$ of $\sim 0.6$. BW cells harboring pACYC177 and pBR322 derivatives were grown overnight at $37^{\circ} \mathrm{C}$ in $3 \mathrm{~mL} \mathrm{LB}$ medium supplemented with $100 \mu \mathrm{g} / \mathrm{mL}$ ampicillin, $25 \mu \mathrm{g} / \mathrm{mL}$ chloramphenicol, $10 \mathrm{mM}$ arabinose, and $10 \mu \mathrm{g} / \mathrm{mL}$ tetracycline in the case of cells harboring pBR322 derivatives. Cells were then used to inoculate $50 \mathrm{~mL}$ of the same medium to a starting $\mathrm{OD}_{578}$ of $0.05-0.1$, followed by incubation at $37^{\circ} \mathrm{C}$. At an $\mathrm{OD}_{578}$ of $\sim 0.5$, cells were centrifuged for $5 \mathrm{~min}$ at $5000 \mathrm{rpm}$ and washed once with $20 \mathrm{~mL} \mathrm{LB}$ to remove residual arabinose. Cells were resuspended in $100 \mathrm{~mL} \mathrm{LB}$ supplemented with antibiotics and $0.5 \%$ glucose and incubated for another $3 \mathrm{~h}$ at $37^{\circ} \mathrm{C}$ and $180 \mathrm{rpm}$. Total cellular RNA from strains DW2 and BW was isolated by the TRIzol method (Invitrogen) according to the protocol provided by the manufacturer. After concentration by ethanol precipitation, RNA was further digested with DNase I (Turbo DNase, Ambion) followed by phenol/ chloroform (1:1) and chloroform extractions (Busch et al. 2000) and ethanol precipitation in the presence of $0.12 \mathrm{M} \mathrm{NaOAc}(\mathrm{pH}$ 5.0). RNA was dissolved in double-distilled $\mathrm{H}_{2} \mathrm{O}$, and concentrations were measured in $\mathrm{H}_{2} \mathrm{O}$ at $260 \mathrm{~nm}\left(1 \mathrm{~A}_{260}\right.$ unit $\left.=40 \mu \mathrm{g}\right)$.

\section{Primer extension assays}

Primer extension assays were performed with total cellular RNA and primers specific to E. coli RNase P RNA (5'-CTC ACT GGC TCA AGC AGC CT), E. coli wild-type 4.5S RNA (5'-GGA GAA CCA ACA GAG CCC), or E. coli mutant 4.5S RNA (5'-GGA GAA CCA ACA GAC GGG). Primer annealing was conducted in 75 $\mathrm{mM} \mathrm{KCl}$ and $68 \mathrm{mM}$ Tris- $\mathrm{HCl}(\mathrm{pH} 8.3$ ) for $\sim 60$ min applying a linear temperature gradient from $90^{\circ} \mathrm{C}$ to $55^{\circ} \mathrm{C}$. Reverse trans- cription was then performed at $55^{\circ} \mathrm{C}$ using ThermoScript reverse transcriptase (Invitrogen) according to the manufacturer's instructions. Nucleotide (dNTP) concentrations in primer extension assays were $0.5 \mathrm{mM}$ each. For primer extension assays to verify expression of E. coli rnpBC292/293 mutant alleles, dGTP was replaced with ddGTP. For the size marker in Figure 3, lane 1, 0.5 $\mathrm{mM}$ dGTP and $0.5 \mathrm{mM}$ ddGTP were used.

\section{Partial purification of RNase P from E. coli cells}

DW2 cells grown at $43^{\circ} \mathrm{C}$ as described (see RNA Isolation for Primer Extension Analysis) and resuspended in $\sim 4 \mathrm{~mL}$ buffer A (60 $\mathrm{mM} \mathrm{NH}_{4} \mathrm{Cl}, 10 \mathrm{mM} \mathrm{Mg}[\mathrm{OAc}]_{2}, 6 \mathrm{mM}$ DTT, $50 \mathrm{mM}$ Tris- $\mathrm{HCl}$ at $\mathrm{pH} 7.2-7.5)$ per $600 \mathrm{mg}$ cell pellet were lysed by sonication (Branson Sonifier 250, output 20, duty cycle 30\%-40\%, $10 \mathrm{~min}$ on ice), followed by centrifugation for $45 \mathrm{~min}$ at $4^{\circ} \mathrm{C}$ and $10,000 \mathrm{~g}$. For the preparation of DEAE fractions, the supernatant was loaded onto a DEAE fast flow Sepharose column (Aekta basic, Pharmacia). Elution was performed by applying a continuous $\mathrm{NH}_{4} \mathrm{Cl}$ gradient from $60-550 \mathrm{mM} \mathrm{NH} \mathrm{NH}_{4} \mathrm{Cl}$. Active fractions eluted at $\sim 300-400 \mathrm{mM} \mathrm{NH}_{4} \mathrm{Cl}$.

\section{Preparation of recombinant RNase $\mathbf{P}$ protein}

E. coli RNase $\mathrm{P}$ protein carrying an N-terminal His-tag (Histagged peptide leader: MRGSHHHHHHGS, encoded in plasmid pQE-30 in E. coli JM109) was expressed essentially as described (Rivera-León et al. 1995). Cell cultures (LB broth containing 100 $\mu \mathrm{g} / \mathrm{mL}$ ampicillin) were grown to an $\mathrm{OD}_{578}$ of 0.6 , and IPTG was added to a final concentration $1 \mathrm{mM}$. Cells were harvested after $3 \mathrm{~h}\left(\mathrm{OD}_{578} \sim 2.5\right)$ by centrifugation for $10 \mathrm{~min}$ at $5000 \mathrm{rpm}$ at $4^{\circ} \mathrm{C}$. The following steps were performed at $4^{\circ} \mathrm{C}$ or on ice, and all buffers contained $40 \mu \mathrm{g} / \mathrm{mL}$ of the protease inhibitor phenylmethylsulfonyl fluoride (PMSF). Cells were then resuspended in 10-15 mL sonication buffer SB (50 mM Tris- $\mathrm{HCl}$ at $\mathrm{pH} 8.0,0.3 \mathrm{M}$ $\mathrm{NaCl}, 0.1 \%$ triton $\mathrm{X}-100,1 \mathrm{M} \mathrm{NH}_{4} \mathrm{Cl}$ ). After sonication (Branson Sonifier 250 , output 20 , duty cycle $50 \%, 15 \mathrm{~min}$ on ice), the sample was centrifuged for $30 \mathrm{~min}\left(4^{\circ} \mathrm{C}, 14,500 \mathrm{~g}\right)$, and the supernatant was mixed with Ni-NTA agarose $(400 \mu \mathrm{L}$ for $2 \mathrm{~L}$ of cell culture), which had been prewashed twice with $10 \mathrm{~mL} S B$ buffer. The sample was incubated for $1-2 \mathrm{~h}$ at $4^{\circ} \mathrm{C}$ under gentle mixing or rotating. The Ni-NTA agarose slurry was washed three times (centrifugation-resuspension cycles; centrifugation at $4^{\circ} \mathrm{C}$ and $8500 \mathrm{rpm}$ in a desktop centrifuge) with ice-cold washing buffer $(30 \mathrm{mM}$ imidazol, $50 \mathrm{mM}$ Tris- $\mathrm{HCl}$ at $\mathrm{pH} 8.0,8 \mathrm{M}$ urea, $0.1 \%$ triton $\mathrm{X}-100$ ). The RNase $\mathrm{P}$ protein started to precipitate during this procedure; therefore, the supernatant after each washing step was removed carefully to avoid release of protein aggregates from the matrix. The protein was then eluted with 500 $\mu \mathrm{L}$ elution buffer (50 mM Tris- $\mathrm{HCl}$ at $\mathrm{pH} 7.0,10 \%$ glycerol, $7 \mathrm{M}$ urea, $20 \mathrm{mM}$ EDTA, $0.3 \mathrm{M}$ imidazol) for $45 \mathrm{~min}$ at $4^{\circ} \mathrm{C}$ under gentle shaking. Eluates were dialyzed twice for $1 \mathrm{~h}$ and subsequently overnight against volumes of $500 \mathrm{~mL}$ dialysis buffer $(50$ $\mathrm{mM}$ Tris- $\mathrm{HCl}$ at $\mathrm{pH} 7.0,0.1 \mathrm{M} \mathrm{NaCl}, 10 \%$ glycerol; dialysis bags: Roth, molecular weight cut off $12-14 \mathrm{kDa}$ ); during dialysis, a white precipitate forms. The content of the dialysis bags was transferred to a 2-mL Eppendorf tube and centrifuged for $20 \mathrm{~min}$ at $4^{\circ} \mathrm{C}$ and $12,000 \mathrm{rpm}$ in a desktop centrifuge. The supernatant contained RNase $\mathrm{P}$ protein devoid of any RNase $\mathrm{P}$ RNA contamination, whereas the pellet included traces of RNase $\mathrm{P}$ 
RNA and was therefore discarded. All purification steps were monitored by $17 \%$ SDS-PAGE to assess the purity and concentration of RNase $\mathrm{P}$ proteins.

\section{Processing assays}

For RNase P-catalyzed processing of T. thermophilus ptRNA ${ }^{\text {Gly }}$ (ptRNAwt), or $\mathrm{G}_{74}$ or $\mathrm{G}_{75}$ variants thereof, active DEAE fractions (0.25-1.0 $\mu \mathrm{L}$; equal amounts [0.004 $\mathrm{A}_{260}$ units] based on $\mathrm{A}_{260}$ measurements) were incubated in buffer A (2 or $10 \mathrm{mM}$ $\mathrm{Mg}[\mathrm{OAc}]_{2}, 6 \mathrm{mM}$ DTT, $50 \mathrm{mM}$ Tris- $\mathrm{HCl}$ at $\mathrm{pH}$ 7.5) containing $100 \mathrm{mM} \mathrm{NH}_{4} \mathrm{Cl}$ for $10 \mathrm{~min}$ at $37^{\circ} \mathrm{C}$ in a volume of $16 \mu \mathrm{L}$. Trace amounts $(<1 \mathrm{nM})$ of the $5^{\prime}$-endlabeled ptRNA ${ }^{\text {Gly }}$ substrate were preincubated under the same conditions for $5 \mathrm{~min}$ at $55^{\circ} \mathrm{C}$ and 25 min at $37^{\circ} \mathrm{C}$. Processing reactions were started by combining enzyme and substrate solutions (final volume, $20 \mu \mathrm{L}$ ) and assayed at $37^{\circ} \mathrm{C}$. The $\mathrm{Mg}(\mathrm{OAc})_{2}$ concentration was raised to $100 \mathrm{mM}$ in control reactions with $E$. coli RNase P RNA alone. Buffer KN [20 $\mathrm{mM}$ Hepes- $\mathrm{KOH}$ at $\mathrm{pH} 7.4,2$ or $4.5 \mathrm{mM} \mathrm{Mg}(\mathrm{OAc})_{2}, 150 \mathrm{mM}$ $\mathrm{NH}_{4} \mathrm{OAc}, 2 \mathrm{mM}$ spermidine, $0.05 \mathrm{mM}$ spermine, and $4 \mathrm{mM}$ $\beta$-mercaptoethanol] (Dinos et al. 2004), optimized for functional analyses of E. coli ribosomes, was used to closely mimic physiological conditions. In vitro reconstitution of RNase P holoenzymes was performed as follows: RNase P RNAs were incubated in buffer $\mathrm{KN}$ for $5 \mathrm{~min}$ at $55^{\circ} \mathrm{C}$ and $50 \mathrm{~min}$ at $37^{\circ} \mathrm{C}$, after which RNase $\mathrm{P}$ protein was added, followed by another $5 \mathrm{~min}$ at $37^{\circ} \mathrm{C}$ before addition of substrate.

\section{Folding analysis by native PAGE}

We incubated $50 \mathrm{fmol}$ of E. coli wild-type or C292/C293 mutant RNase P RNA, including trace amounts of $5^{\prime}$ - or $3^{\prime}$-endlabeled material of the same RNA, in buffer A $\left(100 \mathrm{mM} \mathrm{NH}_{4} \mathrm{Cl}, 6 \mathrm{mM}\right.$ DTT, $50 \mathrm{mM}$ Tris- $\mathrm{HCl}$ at $\mathrm{pH} 7.2-7.5$, and 2 or $10 \mathrm{mM}$ $\left.\mathrm{Mg}[\mathrm{OAc}]_{2}\right)$ or buffer $\mathrm{KN}(20 \mathrm{mM}$ Hepes- $\mathrm{KOH}$ at $\mathrm{pH} 7.4,150$ $\mathrm{mM} \mathrm{NH} \mathrm{NH}_{4} \mathrm{OAc}, 2 \mathrm{mM}$ spermidine, $0.05 \mathrm{mM}$ spermine, $4 \mathrm{mM}$ $\beta$-mercaptoethanol, and 2 or $\left.4.5 \mathrm{mM} \mathrm{Mg}[\mathrm{OAc}]_{2}\right)$ in a volume of $5 \mu \mathrm{L}$ or $4 \mu \mathrm{L}$ if protein was added thereafter. Buffer conditions were the same as those used for the kinetic experiments. RNase $\mathrm{P}$ RNAs were either kept at $4^{\circ} \mathrm{C}$ (no preincubation) or preincubated for $55 \mathrm{~min}$ at $37^{\circ} \mathrm{C}$, or $5 \mathrm{~min}$ at $55^{\circ} \mathrm{C}$ followed by $50 \mathrm{~min}$ at $37^{\circ} \mathrm{C}$. We also tested a preincubation protocol starting with $2 \mathrm{~min}$ at $85^{\circ} \mathrm{C}$, followed by $5 \mathrm{~min}$ at $55^{\circ} \mathrm{C}$ and $50 \mathrm{~min}$ at $37^{\circ} \mathrm{C}$. The results were, however, identical to those obtained with $5 \mathrm{~min}$ at $55^{\circ} \mathrm{C}$ plus $50 \mathrm{~min}$ at $37^{\circ} \mathrm{C}$. For samples including the protein subunit, $1 \mu \mathrm{L}$ of E. coli C5 protein was added (final concentration, $50 \mathrm{nM}$ ) after the preincubation step. All samples, except for those kept at $4^{\circ} \mathrm{C}$, were then incubated for another $15 \mathrm{~min}$ at $37^{\circ} \mathrm{C}$ and finally adjusted to room temperature. Immediately before gel loading, 1 volume of loading buffer (10\% [v/v] glycerol, $2 \mathrm{mM} \mathrm{MgCl}_{2}$, xylene cyanol, bromphenol blue) was added. The nondenaturing $11.25 \%(\mathrm{v} / \mathrm{v})$ polyacrylamide gels (thickness $<1 \mathrm{~mm}$ ) contained 66 $\mathrm{mM}$ Hepes, $33 \mathrm{mM}$ Tris ( $\mathrm{pH} 7.4)$, and $0.1 \mathrm{mM}$ EDTA ( $1 \times \mathrm{THE})$, supplemented with $100 \mathrm{mM} \mathrm{NH} \mathrm{m}_{4} \mathrm{OAc}$ and 2 or $10 \mathrm{mM} \mathrm{MgCl}_{2}$. Gels were run at 180-250 V until xylene cyanol had migrated 11.5 $\mathrm{cm}$ from the top. The gel temperature was controlled not to exceed $15^{\circ} \mathrm{C}$. The RNA bands were visualized with a Bio-Imaging Analyzer (FLA 3000-2R, Fujifilm). Results were the same for $5^{\prime}$ and $3^{\prime}$-endlabeled RNase P RNAs. End homogeneity of RNase P RNAs was checked by denaturing PAGE. Results for RNase P
RNAs preincubated in buffer $\mathrm{KN}$ containing $4.5 \mathrm{mM} \mathrm{MgCl}_{2}$ were the same if gels were run in the presence of 4.5 or $10 \mathrm{mM} \mathrm{MgCl}_{2}$ (data not shown).

\section{ACKNOWLEDGMENTS}

We thank Agustin Vioque (Universidad de Sevilla, Spain) for providing us with the antiserum specific for the E. coli RNase $\mathrm{P}$ protein, Michal Marszalkowski (Hartmann Laboratory) for preparation of recombinant E. coli RNase P protein, Jean-Marc Ghigo (Institut Pasteur, Paris, France) for putting strain TG1 cat-AraC at our disposal, Jörg Vogel (Max Planck Institute for Infection Biology, Berlin, Germany) for providing plasmid pKD46, and the reviewers for their insightful and encouraging comments. This work was supported by the Deutsche Forschungsgemeinschaft (HA 1672/7-4) and the Fonds der Chemischen Industrie.

Received June 12, 2006; accepted September 5, 2006.

\section{REFERENCES}

Alatossava, T., Jutte, H., Kuhn, A., and Kellenberger, E. 1985. Manipulation of intracellular magnesium content in polymyxin B nonapeptide-sensitized Escherichia coli by ionophore A23187. J. Bacteriol. 162: 413-419.

Altman, S. and Kirsebom, L.A. 1999. The RNA world (eds. R.F. Gesteland et al.), pp. 351-380. Cold Spring Harbor Laboratory Press, Cold Spring Harbor, NY.

Amann, E., Ochs, B., and Abel, K.J. 1988. Tightly regulated tac promoter vectors useful for the expression of unfused and fused proteins in Escherichia coli. Gene 69: 301-315.

Bothwell, A.L., Garber, R.L., and Altman, S. 1976. Nucleotide sequence and in vitro processing of a precursor molecule to Escherichia coli 4.5 S RNA. J. Biol. Chem. 251: 7709-7716.

Brännvall, M., Pettersson, B.M.F., and Kirsebom, L.A. 2003. Importance of the $+73 / 294$ interaction in Escherichia coli RNase P RNA substrate complexes for cleavage and metal ion coordination. J. Mol. Biol. 325: 697-709.

Buck, A.H., Dalby, A.B., Poole, A.W., Kazantsev, A.V., and Pace, N.R. 2005. Protein activation of a ribozyme: The role of bacterial RNase P protein. EMBO J. 24: 3360-3368.

Busch, S., Kirsebom, L.A., Notbohm, H., and Hartmann, R.K. 2000. Differential role of the intermolecular base-pairs $\mathrm{G}^{292-\mathrm{C}_{75}}$ and G293- $\mathrm{C}_{74}$ in the reaction catalyzed by Escherichia coli RNase P RNA. J. Mol. Biol. 299: 941-951.

Ciesiolka, J., Hardt, W.D., Schlegl, J., Erdmann, V.A., and Hartmann, R.K. 1994. Lead-ion induced cleavage of RNase P RNA. Eur. J. Biochem. 219: 49-56.

Datsenko, K.A. and Wanner, B.L. 2000. One-step inactivation of chromosomal genes in Escherichia coli K-12 using PCR products. Proc. Natl. Acad. Sci. 97: 6640-6645.

Day-Storms, J.J., Niranjanakumari, S., and Fierke, C.A. 2004. Ionic interactions between P RNA and P protein in Bacillus subtilis RNase $\mathrm{P}$ characterized using a magnetocapture-based assay. RNA 10: $1595-1608$.

Dinos, G., Wilson, D.N., Teraoka, Y., Szaflarski, W., Fucini, P., Kalpaxis, D., and Nierhaus, K.H. 2004. Dissecting the ribosomal inhibition mechanisms of edeine and pactamycin: The universally conserved residues G693 and C795 regulate P-site RNA binding. Mol. Cell 13: 113-124.

Evans, D., Marquez, S.M., and Pace, N.R. 2006. RNase P: Interface of the RNA and protein worlds. Trends Biochem. Sci. 31: 333-341.

Guerrier-Takada, C., Gardiner, K., Marsh, T., Pace, N., and Altman, S. 1983. The RNA moiety of ribonuclease $P$ is the catalytic subunit of the enzyme. Cell 35: 849-857. 
Hardt, W.D. and Hartmann, R.K. 1996. Mutational analysis of the joining regions flanking helix P18 in E. coli RNase P RNA. J. Mol. Biol. 259: 422-433.

Hardt, W.D., Schlegl, J., Erdmann, V.A., and Hartmann, R.K. 1995. Kinetics and thermodynamics of the RNase P RNA cleavage reaction: Analysis of tRNA 3'-end variants. J. Mol. Biol. 247: 161-172.

Harris, M.E. and Christian, E.L. 2003. Recent insights into the structure and function of the ribonucleoprotein enzyme ribonuclease P. Curr. Opin. Struct. Biol. 13: 325-333.

Hartmann, E. and Hartmann, R.K. 2003. The enigma of ribonuclease P evolution. Trends Genet. 19: 561-569.

Hartmann, R.K., Heinrich, J., Schlegl, J., and Schuster, H. 1995. Precursor of C4 antisense RNA of bacteriophages P1 and P7 is a substrate for RNase P of Escherichia coli. Proc. Natl. Acad. Sci. 92: $5822-5826$.

Heide, C., Pfeiffer, T., Nolan, J.M., and Hartmann, R.K. 1999. Guanosine 2- $\mathrm{NH}_{2}$ groups of Escherichia coli RNase P RNA involved in intramolecular tertiary contacts and direct interactions with tRNA. RNA 5: 102-116.

Hsu, L.M., Zagorski, J., and Fournier, M.J. 1984. Cloning and sequence analysis of the Escherichia coli 4.5 S RNA gene. J. Mol. Biol. 178: 509-531.

Kim, K.S., Sim, S., Ko, J.H., and Lee, Y. 2005. Processing of M1 RNA at the $3^{\prime}$ end protects its primary transcript from degradation. J. Biol. Chem. 280: 34667-34674.

Kirsebom, L.A. and Svärd, S.G. 1994. Base pairing between Escherichia coli RNase P RNA and its substrate. EMBO J. 13: 4870-4876.

Kufel, J. and Kirsebom, L.A. 1998. The P15-loop of Escherichia coli RNase P RNA is an autonomous divalent metal ion binding domain. RNA 4: 777-788.

Li, Y., Cole, K., and Altman, S. 2003. The effect of a single, temperature-sensitive mutation on global gene expression in Escherichia coli. RNA 9: 518-532.
Lindell, M., Brännvall, M., Wagner, E.G., and Kirsebom, L.A. 2005. Lead(II) cleavage analysis of RNase P RNA in vivo. RNA 11: 13481354.

Oh, B.K., Frank, D.N., and Pace, N.R. 1998. Participation of the $3^{\prime}-$ CCA of tRNA in the binding of catalytic $\mathrm{Mg}^{2+}$ ions by ribonuclease P. Biochemistry 37: 7277-7283.

Peck-Miller, K.A. and Altman, S. 1991. Kinetics of the processing of the precursor to $4.5 \mathrm{~S}$ RNA, a naturally occurring substrate for RNase P from Escherichia coli. J. Mol. Biol. 221: 1-5.

Richmond, C.S., Glasner, J.D., Mau, R., Jin, H., and Blattner, F.R. 1999. Genome-wide expression profiling in Escherichia coli K-12. Nucleic Acids Res. 27: 3821-3835.

Rivera-León, R., Green, C.J., and Vold, B.S. 1995. High-level expression of soluble recombinant RNase P protein from Escherichia coli. J. Bacteriol. 177: 2564-2566.

Roux, A., Beloin, C., and Ghigo, J.M. 2005. Combined inactivation and expression strategy to study gene function under physiological conditions: Application to identification of new Escherichia coli adhesins. J. Bacteriol. 187: 1001-1013.

Schön, A. 1999. Ribonuclease P: The diversity of a ubiquitous RNA processing enzyme. FEMS Microbiol. Rev. 23: 391-406.

Svärd, S.G., Kagardt, U., and Kirsebom, L.A. 1996. Phylogenetic comparative mutational analysis of the base-pairing between RNase P RNA and its substrate. RNA 2: 463-472.

Tabor, S. and Richardson, C.C. 1985. A bacteriophage T7 RNA polymerase/promoter system for controlled exclusive expression of specific genes. Proc. Natl. Acad. Sci. 82: 1074-1078.

Torres-Larios, A., Swinger, K.K., Krasilnikov, A.S., Pan, T., and Mondragon, A. 2005. Crystal structure of the RNA component of bacterial ribonuclease P. Nature 437: 584-587.

Waugh, D.S. and Pace, N.R. 1990. Complementation of an RNase P RNA $(r n p B)$ gene deletion in Escherichia coli by homologous genes from distantly related eubacteria. J. Bacteriol. 172: 6316-6321.

Zarrinkar, P.P., Wang, J., and Williamson, J.R. 1996. Slow folding kinetics of RNase P RNA. RNA 2: 564-573. 

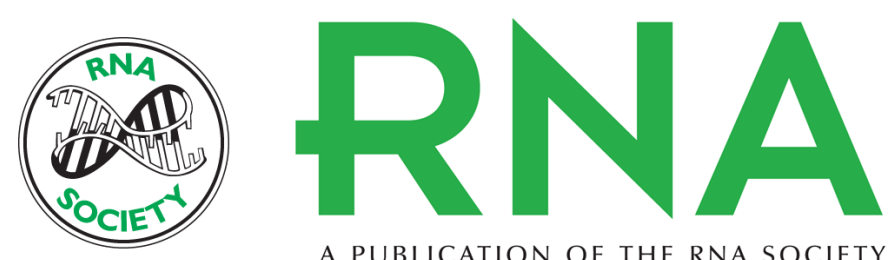

A PUBLICATION OF THE RNA SOCIETY

\section{The precursor tRNA 3'-CCA interaction with Escherichia coli RNase P RNA is essential for catalysis by RNase $P$ in vivo}

Barbara Wegscheid and Roland K. Hartmann

RNA 2006 12: 2135-2148 originally published online October 24, 2006

Access the most recent version at doi:10.1261/rna.188306

\section{References This article cites 35 articles, 17 of which can be accessed free at:}

http://rnajournal.cshlp.org/content/12/12/2135.full.html\#ref-list-1

\section{License}
Email Alerting Receive free email alerts when new articles cite this article - sign up in the box at the Service top right corner of the article or click here.

To subscribe to RNA go to:

http://rnajournal.cshlp.org/subscriptions 